Article

\title{
Eco-Efficient Analysis of a Refurbishment Proposal for a Social Housing
}

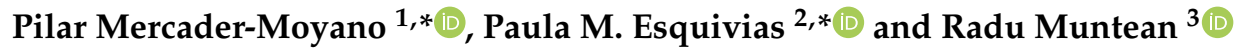 \\ 1 Departamento de Construcciones Arquitectónicas I, Escuela Técnica Superior de Arquitectura, \\ Universidad de Sevilla, Avenida de Reina Mercedes n², 41012 Seville, Spain \\ 2 GIR Termotecnia, Departamento de Ingeniería Energética y Fluidomecánica, Universidad de Valladolid, \\ Paseo del Cauce $n^{\circ}$ 59, 47011 Valladolid, Spain \\ 3 Faculty of Civil Engineering, Transilvania University of Brașov, 500152 Brașov, Romania; radu.m@unitbv.ro \\ * Correspondence: pmm@us.es (P.M.-M.); paula.esquivias@uva.es (P.M.E.)
}

Received: 31 July 2020; Accepted: 18 August 2020; Published: 19 August 2020

check for updates

\begin{abstract}
In recent years, the building sector has been turning towards intervening in the existing city building stock. In fact, it is generally accepted that the refurbishment of buildings based on sustainability must form the axis of reformulation of the building sector. Although energy refurbishment is commonly accepted and recommended towards decarbonization of the building stock, an integral assessment towards implementing the principles of the circular economy must incorporate the environmental impact of the materials in order to get an eco-efficient refurbishment. The article presents the environmental analysis of a social housing located in Cadiz (Spain) and the improvements achieved by its refurbishment. This intervention is improved by incorporating eco-efficient materials based on the environmental and life cycle analysis (LCA). Those analyses are performed using EnergyPlus, Radiance, LCA standards, and Environmental Product Declaration of the products. The results shown that although an energy rehabilitation intervention can fulfil other eco-efficient aspects, an integral assessment should always be carried out in order to ensure that indoor comfort is achieved, daylighting and solar heat gains are balanced, and the environmental impact at product, use, and end-of-life stages of a building is minimized. Considering the constrains and limitations of the tools and databases, higher efforts should be done to solve them and provide useful resources for a decarbonized and circular building stock.
\end{abstract}

Keywords: eco-efficient refurbishment; social housing; circular economy; decarbonization

\section{Introduction}

The European Union (EU) is committed to establish a sustainable, competitive, secure, and decarbonized energy system [1] in which buildings have a capital importance for the energy efficiency policy of the EU. The building sector is one of the most resource consuming sectors in Europe as it represents around $36 \%$ of greenhouse emissions, $40 \%$ of the final energy consumption, $50 \%$ of extracted materials, $30-50 \%$ material resource use, $21 \%$ of total water abstracted, and is responsible for over $35 \%$ of the EU's total waste generation with very significant life cycle impacts, particularly associated with extraction and processing stages [1-6].

The recently approved European Green Deal [2] boosts the efficient use of resources in order to get a clean and circular economy. In the building sector, this objective implies reducing life cycle impact at the same time as providing healthy and comfortable spaces [4] by reducing whole life carbon consumption, increasing reused and recycled content, and a sustainable management of construction and demolition waste, getting what is called circular buildings. This term is used to define a building 
that is designed, planned, built, operated, maintained, and deconstructed in a manner consistent with circular economy principles [7].

A circular economy is one "that is restorative and regenerative by design and aims to keep products, components and materials at their highest utility and value at all times'" [8]. The European Union states that "in a circular economy the value of products, materials and resources is maintained in the economy for as long as possible. Waste and resource use are minimized, and when a product reaches the end of its life, it is used again to create further value" [9]. The circular economy in the building sector is an approach aiming at minimizing waste and emissions, as well as closing water, energy, and material loops. Under a circular built environment, landfilling is no longer an option to handle construction and demolition waste, and design for disassembly has a central role. Design for disassembly is a concept in which buildings and products are designed intentionally for material recovery, value retention, and meaningful next use [10].

'Sustainability' and 'circular economy' have received increasing attention in the last decade, although these concepts were introduced in the mid-20th century. However, despite the several definitions or descriptions they have received, the similarities and differences between both concepts remain ambiguous [11,12]. Both concepts are based on the environmental awareness but how they relate to each other remains unclear or not addressed at all, blurring their conceptual contours. Anastasiades et al. [12] expose a definition for what they call a "Moderate sustainability". This definition implies a combination of technological advances to solve environmental problems and of users' habits to reduce the demand from nature. However, the circular economy also acknowledges the fact that user behavior will need to change and the incorporation of technological advances in order to close the material, energy, and water flows. Thus, as Anastasiades et al. state "sustainability is the goal, while the circular economy is a mean to achieve a more sustainable economy" [12].

Under the framework of the new Circular Economy Action Plan [5], the Commission will launch a new comprehensive Strategy for a Sustainable Built Environment that will promote circularity principles throughout the lifecycle of buildings in order to increase the material efficiency and reduce the climate impacts. This strategy will promote the sustainable performance of construction products, the durability and adaptability of built assets, the decarbonization of the materials and energy resources of the building stock, the recovery of materials, and a sustainable use of excavated soils. These actions are in line with the 'Renovation Wave' initiative [13] for public and private buildings as boosting energy performance of buildings means consuming less energy and saving money, helping to alleviate energy poverty and improve comfort, sanitary, and living conditions addressing the twin challenge of energy efficiency and affordability.

In this context, circularity and sustainability need to be assessed over the whole life cycle of the building to optimize reduction of carbon emissions and material flows [4].

The final energy consumption of buildings is mainly dedicated to heating and cooling, so their decarbonization is fundamental [1,2,14-16]. The energy efficiency requirements for buildings have been gradually increased towards nearly zero-energy buildings (nZEB) [1], expressed in the European Directives [17-19], for new [20] and existing buildings in order to get in 2050 a decarbonized building stock, so existing buildings must also move towards nZEB [14,15].

Nowadays, two-thirds of the EU's buildings were built when energy efficiency requirements were limited or non-existent and around $70 \%$ of the buildings that we will occupy in 2050 are already built $[15,21]$. Ninety-seven percent of the existing buildings built before 2010 require a partial or total refurbishment in order to fulfil the objectives for 2050. Following the goal "Putting energy efficiency first" [3] implies to admit that the most cheap and clean energy is the energy that does not need to be produced or used $[1,19,20]$. Added to this is the fact that 50 million Europeans live in energy poverty conditions, due to the effort of paying high energy bills in order to keep their inefficient homes comfortable [2].

Energy poverty is a common issue in social housing all over Europe due to the low-income level of their inhabitants. It has a harder impact in Southern European countries, despite more favorable 
climatic conditions, due to the poorer insulation of the buildings, the inefficiency of the thermal equipment installed, and the lack of energy efficient users' habits [22]. Some of them are owned and managed by public institutions that undertake the required interventions to maintain the habitability of the dwellings. Facing an energy refurbishment in these cases not only improves the indoor health and comfort conditions, but also reduces the energy bills of the public institutions, allowing them to dedicate that investment to other public services or reducing the risk for users of getting into debt with the institution if they are responsible of the bills.

Energy consumption during the use phase of the building is covered by various EU regulations, but looking throughout the whole life of the building, the energy used in the manufacture of construction product and during the construction process of the building also has an important role. In fact, $5-10 \%$ of total energy consumption in EU is related to the manufacture of construction products [23]. Greenhouse gas emissions from material extraction, manufacturing of construction products, and construction and renovation of buildings are estimated at $5-12 \%$ of total national GHG emissions [5]. Greater material efficiency could save $80 \%$ of those emissions.

However, an eco-efficient building looks beyond the greenhouse gas emissions: It also considers the other resources comprised in the building's life cycle. The construction sector has large potential for circular economy given the scale of material use, value contained in buildings, labor intensiveness, and long-term effect of measures [4]. The material requirement of buildings currently represents one of the greatest resource use challenges in terms of mass of resources used [6]. It mainly consists of iron, aluminum, copper, clay, sand, gravel, limestone, wood, and building stone. Minerals have the highest share of all materials in buildings. Around $65 \%$ of total aggregates (sand, gravel, and crushed rock) and approximately $20 \%$ of total metals are used by the construction sector. Data and information collected on use of construction materials suggest that concrete, aggregate materials (sand, gravel, and crushed stone), and bricks make up to $90 \%$ (by weight) of all materials used [6]. Construction and demolition waste (CDW), when measured in volume, is the largest waste stream in the EU. Even though a vast majority of CDW is recyclable, one common hurdle to recycling and re-using CDW in the EU is the lack of confidence in the quality of these recycled materials [24].

A building and construction sector that optimizes the use of resources and results in zero waste to landfill is the level of ambition the sector must achieve. This can only be achieved by keeping materials and resources in use as long as possible. The measures are based on incorporating recycled content and reducing resource waste in the manufacturing process of construction products; designing and carefully planning the interventions in order to minimize the use of new materials, select environmentally friendly construction products, and choose the most energy efficient proposal; and establishing an adequate construction and demolition waste management in order to recover materials of such quality that can be reincorporated as recycled or re-used materials [23,25-27].

The recycling or reuse of materials or even whole products is increasingly important as a means to improve the efficient use of materials and to avoid negative impacts associated with virgin material [23]. Furthermore, the European Strategy for a Sustainable Built Environment, which will be released in 2021, will introduce requirements for recycled content and waste reduction measures in construction products and materials so it will contribute to preventing a mismatch between supply and demand of secondary raw materials and ensure the smooth expansion of the recycling sector in the EU [5] as improved recycling could reduce GHGs by $14-18 \%$ in 2050 in the G7 [27]. As part of the revision of the recovery targets for construction and demolition waste, the Commission will pay special attention to insulation materials, which generate a growing waste stream [5].

The transition to a low-carbon, circular economy will have far reaching social and economic impacts. Europeans spend approximately $90 \%$ of their time in indoor spaces [28,29]. Indoor environmental quality (indoor air quality, thermal comfort, luminous comfort, and acoustic comfort) plays a significant role in human health, wellbeing, and productivity [28,30-32]; this has been specially highlighted because of the COVID-19 pandemic. The transition should eliminate energy poverty, ensuring adequate 
warmth, cooling, lighting, and the energy to power appliances for guaranteeing health and a decent standard of living for all [33].

A decarbonized, resource-efficient, and circular building stock requires an integral assessment of the proposals, for new and refurbishment of existing buildings, under the point of view of energy efficiency and resource efficiency during the life cycle to achieve clean indoor air and thermal, luminous, and acoustic comfort [20].

Nowadays, the implementation of the building information modelling (BIM) collaborative working methodology allows different specialists to work together over the same model, so the eco-efficient assessment of the building can be performed in a unique platform [30]. Moreover, this methodology is required for public building projects.

Facing that it is habitual that a refurbishment proposal, designed mainly under the energy efficiency point of view, dismisses other eco-efficient aspects, the aim of this work is to perform an integral analysis of a refurbishment proposal. The integral analysis considers the different aspects involved in the principles of energy efficiency, resource efficiency, circular economy, human comfort, and health, such as hydrothermal and daylighting indoor conditions and the use of eco-efficient materials.

This research analyzes a conventional refurbishment proposal for social housing using different tools installed as plugins for Revit and corrects the eco-efficient aspects not fulfilled. In 2019, almost 79\% of the building licenses were for residential buildings, $49.26 \%$ of them were dedicated to refurbishment works, and $71.59 \%$ of the refurbishment works were related to interventions on roofs and façades. Furthermore, almost $10 \%$ of the building licenses required by public institutions were for residential buildings [34]. This research was conducted in order to know what would happen if the intervention made to the case study would be based on the actual paradigm of circular economy and eco-efficient refurbishment instead of the energy rating results.

Thus, the starting point of this research is the information about the refurbishment undertook by a public institution on a social housing of its property. It is located in Cadiz, Spain. The mandatory use of BIM tools when working with public institutions was taken as a constraint for the development of the different analyses, and the available Spanish LCA databases were taken as the sites where non-specialists would look for alternative materials.

The 'Materials and methods' section describes firstly the methodology and the tools used to develop this research and secondly exposes the case study and the parameters of the building defined to carried out the simulations. The 'Results' section exposes the data obtained from the tools. It starts with the exposition and observations regarding the environmental performance of the original state of the building and follows with the exposition and observations about the environmental performance and life cycle results of the refurbishment intervention applied to the building and the alternative proposal, correcting those eco-efficient aspects that do not fulfil the original intervention. This is followed by a discussion of our findings. The paper concludes with final remarks on the contributions of this research.

\section{Materials and Methods}

\subsection{Methodology}

As this work discusses and looks for proposals for rehabilitation and reparation of buildings that differ from the conventional ones, the starting point is a building that has been conventionally refurbished in order to get the previous state and the conventional intervention carried out.

Building location, geometry, constructive characteristics of its original state and the refurbishment solution, hydrothermal measurements before and after the intervention, and energy rating model before and after the intervention were provided by the owner of the building.

In order to analyze what would happen if the intervention would have been proposed under the eco-efficiency and circular economy paradigm, the following steps have been carried out: 
1. Analysis of the environmental performance of the original stage.

a. Energy demand analysis.

i. Provided measurements.

ii. Provided energy rating results.

iii. Energy simulation using EnergyPlus.

b. Daylighting and solar access analyses.

2. Integral analysis of the original intervention.

a. Energy demand analysis.

i. $\quad$ Provided measurements.

ii. Provided energy rating results.

iii. Energy simulation using EnergyPlus.

b. Daylighting and solar access analysis.

c. Life cycle analysis.

3. Proposal and integral analysis of an alternative intervention.

a. Definition of the proposal based on the eco-efficient aspects not fulfilled previously.

b. Analysis of the eco-efficient aspects rectified.

The owner carried out a monitoring campaign in order to assess the impact of its investment. Furthermore, the government has approved some tools to be used for energy rating of existing buildings. One of these official tools has been used by the owner to get the energy certification of the building, at its original state and after the refurbishment. In addition, it is mandatory to use BIM tools when working with public institutions. These three contextual aspects constrain and compose the tools used to develop the research. They are exposed in the following sections.

\subsubsection{Building Monitoring Campaign}

In order to assess the impact of the original intervention, a monitoring campaign was carried out starting before the works and ending a year and two months after them. The monitored data began on 23 October 2014 and finished on 10 May 2016 and the refurbishment works started on 21 November 2014 and ended on 21 January 2015.

Temperature and relative humidity were measured using OM-E8-USB-2-LCD sensors. This sensor measures dry bulb temperature $\left({ }^{\circ} \mathrm{C}\right)$ and relative humidity (\%) within a range of $-35^{\circ} \mathrm{C}$ to $80^{\circ} \mathrm{C}$ and $0 \%$ to $100 \%$ and accuracy of $\pm 0.5{ }^{\circ} \mathrm{C}$ and $\pm 3.0 \%$. This device can register data with a time-step from $10 \mathrm{~s}$ to $12 \mathrm{~h}$ and can record up to 16,379 temperature data and 16,379 humidity data. During the monitoring campaign, data were recorded with a time-step of $1 \mathrm{~h}$.

Monitored data are collected in text files as comma separated values (*.csv). Each file is imported in a spreadsheet in order to get the environmental performance, as well as treat them to get statistical data.

\subsubsection{Energy Certification Model of the Building}

According to the transposition to the Spanish regulation of the Directive 2010/31/EU [17], it is mandatory for existing buildings to get the energy performance certificate in order to facilitate it to new tenants or owners of the building or part of it. This energy performance certification should be upgraded when there are interventions in the building that modifies its energy performance.

The energy certification model of the building was created with the recognized software CE3x [35]. This software gets the energy performance certification by parametrizing the input data and compares them with a database containing a high number of experiments simulated with the general procedure 
of energy certification (hourly energy simulation). By default, the general procedure considers that blinds cover $30 \%$ of window surface, which means that $30 \%$ of each window surface is covered by blinds, thus reducing the entrance of solar heat gains.

The input data include the climate zone, type of building, orientation, compactness, ventilation, thermal transmittance of the envelope's elements, windows-to-façade ratio, walls mass, solar heat coefficient, and thermal breaks of the envelope.

Due to the difficulty of obtaining the information about thermal envelope and building services in existing buildings, these data can be introduced under three modes: Known values, estimated values, or values by default. Estimated and by-default values are based on the most common solutions used under each Spanish energy performance standard for each climate zone.

\subsubsection{Building Information Modelling Software and Plugins}

In order to perform an integral analysis covering energy, daylighting, solar exposure, and life cycle, the building was modelled in Revit 2020 version 20.2.12.1 [36]. Revit supports the design, drawings, and schedules required for building information modelling (BIM). BIM is digital prototyping for buildings. It delivers information about project design, scope, quantities, and phases. In the Revit model, every drawing sheet, $2 \mathrm{D}$ and $3 \mathrm{D}$ view, and schedule is a presentation of information from the same virtual building model. Elements are the building blocks of a 3D model. They represent the real-world components and are defined by their parameters (size, shape, position, material, and other information). Revit uses parametric modelling, which refers to the relationship among all elements in a project, enabling the coordination and change management.

\section{Energy Demand Analysis}

The energy demands of the building model in Revit can be determined using the tool "Heating and Cooling Loads Analysis" [37]. This integrated tool uses the Radiant Time Series calculation method for calculating the cooling and heating loads for each component. Loads analysis uses an idealized heating, ventilation, and air conditioning (HVAC) system that simply tabulates these loads at each time interval and then meets them with unlimited capacity.

The feature of Revit 2020 "Systems Analysis" can perform a detailed energy simulation of a building with detailed HVAC systems. It is built using EnergyPlus [38] and OpenStudio in collaboration with the US Department of Energy (DOE) and the National Renewable Energy Laboratory (NREL).

Each dwelling is assumed to be a unique space and is assigned to a HVAC zone when applied or left at the default zone if it is only naturally ventilated. Spaces contain information about the areas in which they have been placed and information about different parameters that affect the heating and cooling loads calculation. Each zone contains information about heating and cooling temperature set points and HVAC type. Revit uses both zone and space information during heating and cooling loads analysis to determine the energy demands of the building.

\section{Daylighting}

Revit also includes an energy optimization module that provides guidance and direction towards better building energy performance in Autodesk Insight [39]. Although Insight is integrated into Revit, there is a plugin that needs to be installed for performing lighting analysis, solar analysis, and accessing the energy optimization panel.

The insight lighting analysis for Revit (LAR) allows for performing several studies regarding to daylighting based on calculating illuminance values on the work plane.

The LAR plug-in uses the Autodesk Rendering cloud service to perform very fast and physically accurate daylighting analyses from within Revit. The Autodesk Rendering cloud service uses bidirectional ray tracing but with an additional intelligent algorithm to determine the ray order such that the most important rays are generated first. This algorithm is called Multidimensional 
Lightcuts [40] and is based on initial research by the Cornell Lighting Lab, which significantly reduces the time and complexity needed to accomplish scalable and consistent illuminance calculations.

The Multidimensional Lightcuts method dynamically determines ray bounces for each target point based on what is needed for ideal results resolution, rather than specifying the same number of bounces for every ray. The method has been validated by comparing Autodesk Rendering illuminance outputs to both Radiance and to actual light level measurements of a space.

The Insight Lighting tool allows to calculate the climate-based daylight metrics spatial daylight autonomy (sDA) and annual sunlight exposure (ASE) [41], standardized by the Illuminating Engineering Society of North America (IESNA) and required for LEED and BREEAM compliance, using the Perez All-Weather Sky model.

Spatial daylight autonomy ( $\mathrm{sDA}_{\text {lux/time }}$ ) is a measure of daylight illuminance sufficiency for a given area, reporting a percentage of floor area that exceeds a specified illuminance (e.g., 300 lux) for a specified percentage of the analysis period (e.g., 50\%). LEED and BREEAM schemes give points if, for a minimum illuminance of 300 lux and 50\% of the analysis period ( 3650 annual hours for LEED, $9 \mathrm{~h}$ until $17 \mathrm{~h}$ for BREEAM), the $\mathrm{SDA}_{300 / 50}$ is higher than a certain value of the room area.

Annual sunlight exposure (ASE $\mathrm{Iux}_{\text {luours }}$ ) is the fraction or percentage of the horizontal work plane that exceeds a specified direct sunlight illuminance level (e.g., 1000 lux) more than a specified number of hours per year (e.g., $250 \mathrm{~h}$ ) of the analysis period (e.g., $3650 \mathrm{~h}$ ) with all operable shading devices retracted. LEED scheme gives points if $\mathrm{ASE}_{1000 / 250}$ is lower than $20 \%$, which means that the percentage of a room area that exceeds 1000 lux over $250 \mathrm{~h}$ of $3650 \mathrm{~h}$ of the year is lower than $20 \%$ of the room area.

The results of the daylighting analysis are reported through color maps that help visualize the percentage of the work plane that meets the illuminance and temporal requirements of each daylighting metric. The values can be also found as a Lighting report.

\section{Solar Access}

The insight lighting analysis for Revit (LAR) also allows to study the direct solar access, being like the solar study performed using a Sun Path. However, the Solar Access option of the LAR only allows for the hours of direct sun over a given day for a time range and a minimum number of hours is required to consider having direct solar access. The Solar Access option automatically uses the CIE Clear Sky model.

The solar study is performed for the three representative days of the year: Summer and winter solstices and spring/autumn equinox from sunrise to sunset. The results are reported through color maps in which the graphical scale is the number of hours of direct sun on the work plane, and through a table with the values got by each room, based on the threshold established.

Life Cycle Analysis

The life cycle analysis is performed using the application Tally [42]. This application allows to quantify the environmental impact of building materials for whole building analysis as well as comparative analyses of design options. While working on a Revit model, the user can define relationships between BIM elements and construction materials from the Tally database.

Tally assessments account for the full cradle-to-grave life cycle of the studied object, including material manufacturing, maintenance and replacement, and eventual end-of-life. Its methodology is consistent with LCA standards ISO 14040-14044:2006 [43,44], ISO 21930:2017 [45], ISO 21931-1:2010 [46], EN 15804:2012+A2:2019 [47], and EN 15978:2011 [48]. Tally utilizes a custom designed LCA database that combines material attributes, assembly details, and architectural specifications with environmental impact data. All Environmental Product Declarations (EPD) listed in Tally include their full life cycle impacts, even if the published EPD only includes the Product stage (A1-A3) in order to compare different products, materials, or assemblies.

LCA modeling is conducted in GaBi 8.5 using GaBi 2018 databases [49]. The data compiled in the $\mathrm{GaBi}$ database are intended to represent 2017 US values. Where representative data are unavailable, 
proxy data are used. The datasets used, their geographic region, and year of reference are listed for each entry. Whenever possible, proxy datasets that are technologically consistent with the relevant entry are chosen.

\subsection{Case Study}

The case study is a social housing located in Cadiz, Spain (Figure 1), at the bayside. The main entrance, by the avenue facing the bay, is rotated $19^{\circ}$ from North so it has an East-North (EN) orientation, with the other façades the following orientations: South-East-South $\left(109^{\circ}\right.$ from North, SES), West-South

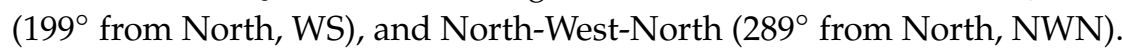

The housing was built in 1988, before the transposition to national regulation of the Directive 2002/91/EC on the energy performance of buildings [50]. It has $1934 \mathrm{~m}^{2}$ built and a height of $23 \mathrm{~m}$, and the base floor is $1.26 \mathrm{~m}$ from the ground. The building hosts 23 dwellings from 56.30 to 84.55 useful $\mathrm{m}^{2}$ distributed on 7 stories. Base and first floor have 4 dwellings each, and second to sixth floor have 3 dwellings each, as shown in Figure 2. Geometrical information about the dwellings can be found in Table 1.

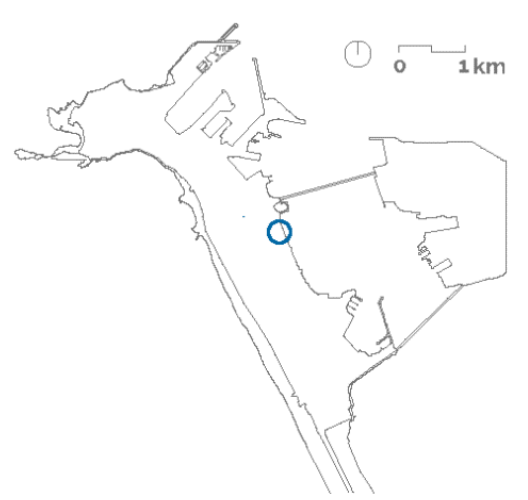

(a)

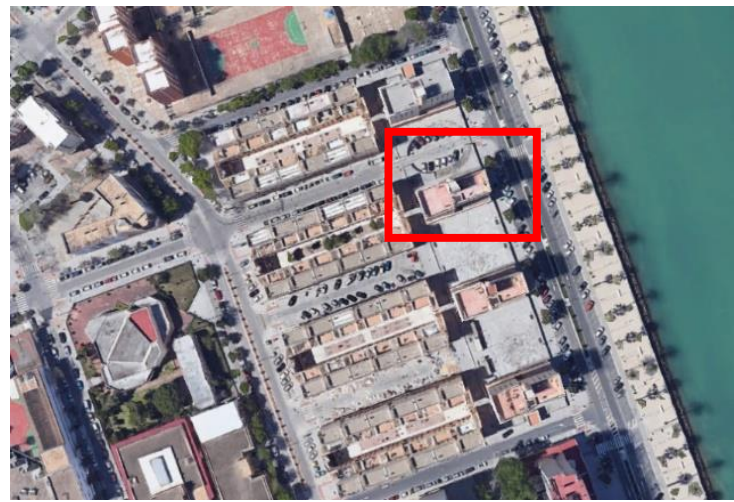

(b)

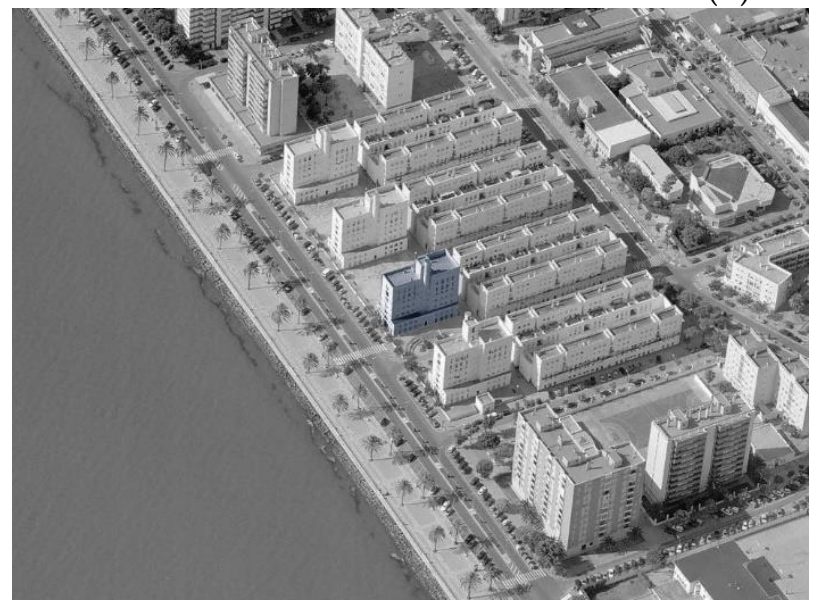

(c)

Figure 1. Site plan of the building under study: (a) Location at Bay of Cadiz; (b) site plan; (c) aerial perspective. ((b,c) Map data (C2020 Instituto Geográfico Nacional, Google). 


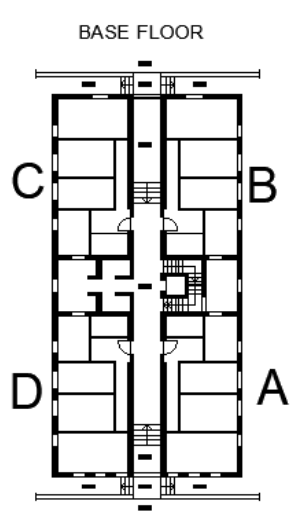

AVDA BAHIA DE CADIZ
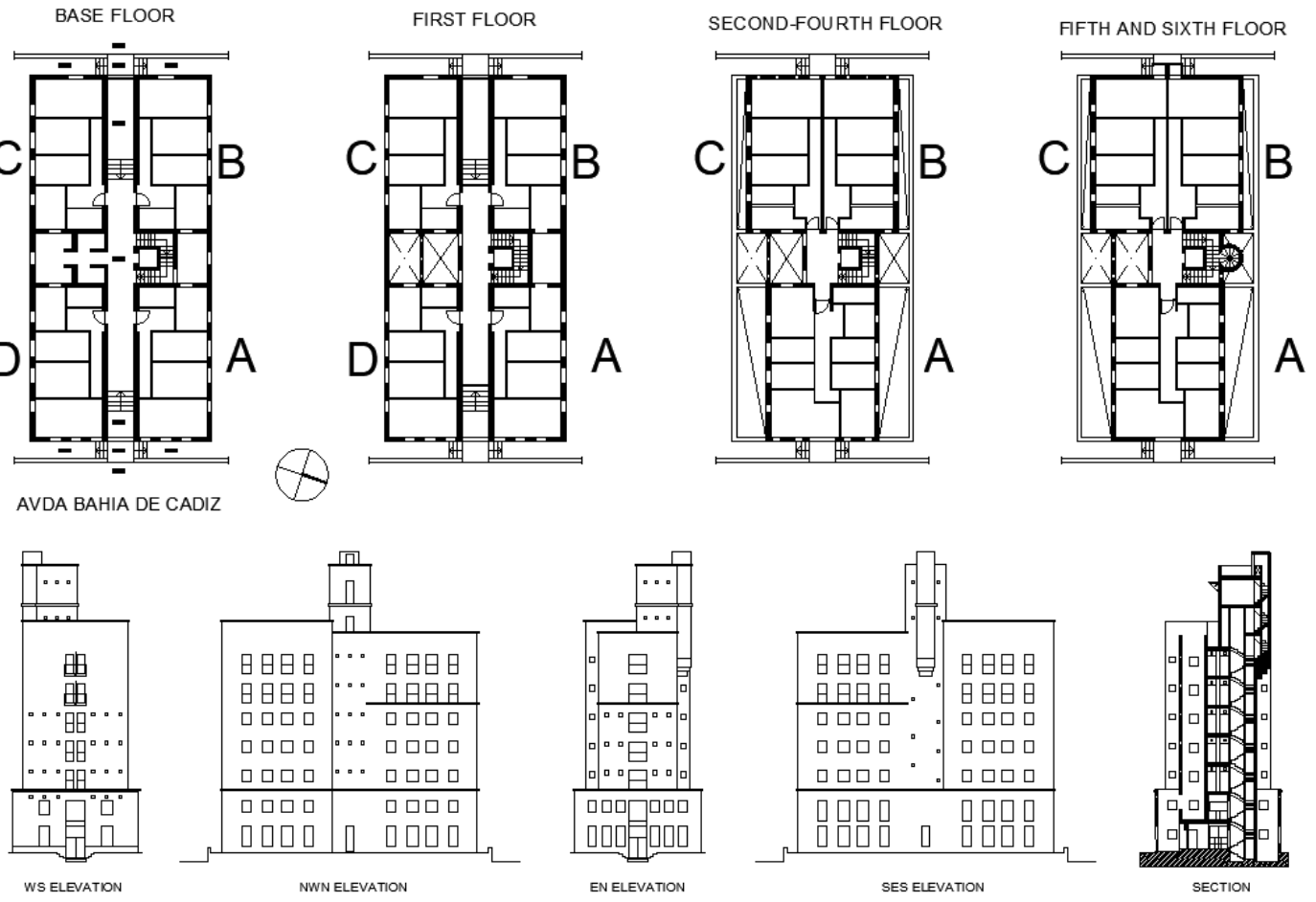

Figure 2. Layouts and elevations of the building.

Table 1. Geometrical information of the envelope

\begin{tabular}{|c|c|c|c|c|c|c|}
\hline Dwelling & Floor $\left(m^{2}\right)$ & Volume $\left(\mathrm{m}^{3}\right)$ & Orientation & Surface $\left(\mathrm{m}^{2}\right)$ & Glazing $\left(\mathrm{m}^{2}\right)$ & Opaque $\left(\mathrm{m}^{2}\right)$ \\
\hline \multirow{5}{*}{$\begin{array}{c}\text { Base A } \\
\text { 1st A }\end{array}$} & \multirow{5}{*}{56.30} & \multirow{5}{*}{154.26} & NWN & 30.50 & 8.82 & 21.68 \\
\hline & & & & 1386 & 5.67 & 8.19 \\
\hline & & & EN & 13.86 & 3.24 & 10.62 \\
\hline & & & WS & 6.51 & 1.00 & 5.51 \\
\hline & & & Roof 1st A & 28.21 & 0.00 & 28.21 \\
\hline \multirow{5}{*}{$\begin{array}{c}\text { Base B } \\
1 \text { st B }\end{array}$} & \multirow{5}{*}{56.30} & \multirow{5}{*}{154.26} & NWN & 30.50 & 8.82 & 21.68 \\
\hline & & & EN & 6.51 & 1.00 & 5.51 \\
\hline & & & WS & 13.86 & 2.52 & 11.34 \\
\hline & & & 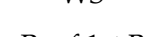 & 10.00 & 2.07 & 11.79 \\
\hline & & & Roof 1st B & 12.23 & 0.00 & 12.23 \\
\hline \multirow{5}{*}{$\begin{array}{c}\text { Base C } \\
\text { 1st C }\end{array}$} & \multirow{5}{*}{56.30} & \multirow{5}{*}{154.26} & $\mathrm{EN}$ & 8.11 & 1.00 & 7.11 \\
\hline & & & SES & 30.50 & 8.82 & 21.68 \\
\hline & & & WS & 13.86 & 2.52 & 11.34 \\
\hline & & & & & 2.07 & 11.79 \\
\hline & & & Roof 1st C & 12.23 & 0.00 & 12.23 \\
\hline \multirow{5}{*}{$\begin{array}{c}\text { Base D } \\
\text { 1st D }\end{array}$} & \multirow{5}{*}{56.30} & \multirow{5}{*}{154.26} & EN & 13.86 & 5.67 & 8.19 \\
\hline & & & & & 3.24 & 10.62 \\
\hline & & & SES & 30.50 & 8.82 & 21.68 \\
\hline & & & WS & 8.11 & 1.00 & 7.11 \\
\hline & & & Roof 1st D & 28.21 & 0.00 & 28.21 \\
\hline \multirow{4}{*}{$\begin{array}{l}\text { 2nd A } \\
\text { 3rd A } \\
\text { 4th A }\end{array}$} & \multirow{4}{*}{84.55} & \multirow{4}{*}{231.67} & NWN & 30.50 & 5.04 & 25.46 \\
\hline & & & EN & 21.21 & 4.41 & 16.80 \\
\hline & & & SES & 30.50 & 5.04 & 25.46 \\
\hline & & & WS & 6.93 & 1.00 & 5.93 \\
\hline 2nd B & \multirow{3}{*}{58.37} & \multirow{3}{*}{159.93} & NWN & 30.50 & 5.04 & 25.46 \\
\hline 3rd B & & & EN & 3.56 & 0.36 & 3.20 \\
\hline 4th B & & & WS & 14.36 & 1.87 & 12.49 \\
\hline 2nd C & \multirow{3}{*}{58.37} & \multirow{3}{*}{159.93} & $\mathrm{EN}$ & 10.96 & 1.36 & 9.60 \\
\hline 3rd C & & & SES & 30.50 & 5.04 & 25.46 \\
\hline 4th C & & & WS & 14.36 & 1.87 & 12.49 \\
\hline
\end{tabular}


Table 1. Cont.

\begin{tabular}{|c|c|c|c|c|c|c|}
\hline Dwelling & Floor $\left(\mathrm{m}^{2}\right)$ & Volume $\left(\mathrm{m}^{3}\right)$ & Orientation & Surface $\left(\mathrm{m}^{2}\right)$ & Glazing $\left(\mathrm{m}^{2}\right)$ & Opaque $\left(\mathrm{m}^{2}\right)$ \\
\hline \multirow{5}{*}{$\begin{array}{l}\text { 5th A } \\
\text { 6th A }\end{array}$} & \multirow{5}{*}{84.55} & \multirow{5}{*}{231.67} & NWN & 30.50 & 8.61 & 21.89 \\
\hline & & & EN & 21.21 & 4.00 & 17.21 \\
\hline & & & SES & 30.50 & 8.61 & 21.89 \\
\hline & & & WS & 6.93 & 1.00 & 5.93 \\
\hline & & & Roof 6th A & 84.55 & 0.00 & 84.55 \\
\hline \multirow{4}{*}{$\begin{array}{l}\text { 5th B } \\
\text { 6th B }\end{array}$} & \multirow{4}{*}{58.37} & \multirow{4}{*}{159.93} & NWN & 30.50 & 8.61 & 21.89 \\
\hline & & & EN & 3.56 & 0.36 & 3.20 \\
\hline & & & WS & 14.36 & 1.60 & 12.76 \\
\hline & & & Roof 6th B & 58.37 & 0.00 & 58.37 \\
\hline \multirow{4}{*}{$\begin{array}{l}\text { 5th C } \\
\text { 6th C }\end{array}$} & \multirow{4}{*}{58.37} & \multirow{4}{*}{159.93} & EN & 10.96 & 1.36 & 9.60 \\
\hline & & & SES & 30.50 & 8.61 & 21.89 \\
\hline & & & WS & 14.36 & 1.60 & 12.76 \\
\hline & & & Roof 6th C & 58.37 & 0.00 & 58.37 \\
\hline \multirow{7}{*}{$\begin{array}{c}23 \\
\text { dwellings }\end{array}$} & \multirow{7}{*}{1456.85} & \multirow{7}{*}{3391.77} & NWN & 426.95 & 99.96 & 326.99 \\
\hline & & & EN & 284.55 & 55.64 & 228.92 \\
\hline & & & SES & 426.95 & 99.96 & 326.99 \\
\hline & & & WS & 262.94 & 35.80 & 227.14 \\
\hline & & & Walls & 1380.18 & 287.36 & 1092.82 \\
\hline & & & Roof & 282.17 & 0.00 & 282.17 \\
\hline & & & Total & 1662.35 & 287.36 & 1374.99 \\
\hline
\end{tabular}

\subsubsection{Constructive Characteristics and Pre-Refurbishment Condition}

The structure is concreted-based, the roof is transitable finished in ceramic tiles, and the façades are composed of double brick walls with an air cavity and thermal insulation (extruded polystyrene, XPS); the external finishing is made with a layer of cement mortar and painted; the internal finishing is made of gypsum mortar; its weight is $188.20 \mathrm{~kg} / \mathrm{m}^{2}$. The base floor is separated from the ground by an air cavity. The floor finishing is terrazzo.

The thermal characteristics of the envelope was regulated by the Spanish standard NBE-CT-79 [51], which limited the thermal transmittance (U-value) for roof, external walls, external floor, and partitions in contact with no heated spaces based on the climate zone. According to this standard, Cadiz is in the $\mathrm{W}$ climate zone, which means that the minimum average temperature in January is around $5{ }^{\circ} \mathrm{C}$. The maximum U-values that are used in the project for this climate zone are shown in Table 2 as well as the U-values of the components of the envelope of the building under study.

Table 2. Maximum U-values for climate zone $\mathrm{W}$ and $\mathrm{U}$-values of the building.

\begin{tabular}{cccc}
\hline Adjacency & Envelope Component & Maximum U-Value $\left(\mathbf{W} / \mathbf{m}^{2} \mathbf{K}\right)$ & Case U-Value $\left(\mathbf{W} / \mathbf{m}^{2} \mathbf{K}\right)$ \\
\hline \multirow{2}{*}{ External } & Roof & 1.40 & 0.53 \\
& Walls $\left(\leq 200 \mathrm{~kg} / \mathrm{m}^{2}\right)$ & 1.20 & 0.56 \\
\hline \multirow{2}{*}{ No heated spaces } & Floors & No value & 1.06 \\
& Interior walls & 2.00 & 0.56 \\
\hline
\end{tabular}

The windows are composed by an aluminum frame, without thermal break and air tightness, and a single pane of $4 \mathrm{~mm}$ of glass. The standard NBE-CT-79 did not require a maximum value but provided an estimated U-value of $5.80 \mathrm{~W} / \mathrm{m}^{2} \mathrm{~K}$ and an estimated air permeability of $100 \mathrm{~m}^{3} / \mathrm{hm}^{2}$. The solar heat gain coefficient (SHGC) of the glazing is 0.85 and the visual transmittance is 0.90 .

Before the refurbishment, the building presented several damages that derived in pathologies to be solved, localized mainly in roofs, external walls, interior finishing, joinery, and sewage service. The deterioration of the roof's waterproof layer derived in high moisture presence under these elements. External walls presented several cracks, which could also be the cause of water infiltration. 


\subsubsection{Climate Data}

The climate data are typical meteorological year (TMY) published in EnergyPlus weather (EPW) format. TMYx files are derived from hourly weather data through 2018 in the integrated surface database (ISD) [52] using the ISO 15927-4:2005 methodology [53]. ISD individual year files are created using the general principles from the IWEC (International Weather for Energy Calculations) Typical Meteorological Years that was published in 2001. The resultant files have been peer reviewed by interested parties [54].

The climate data of Cádiz are taken from the WMO Station "CÁDIZ OBS", number 084520 $\left(36^{\circ} 29^{\prime} 59.0^{\prime \prime} \mathrm{N} 6^{\circ} 15^{\prime} 28.0^{\prime \prime} \mathrm{W}\right)$ located near the case study at $9 \mathrm{~m}$ above sea level (Figure 3).

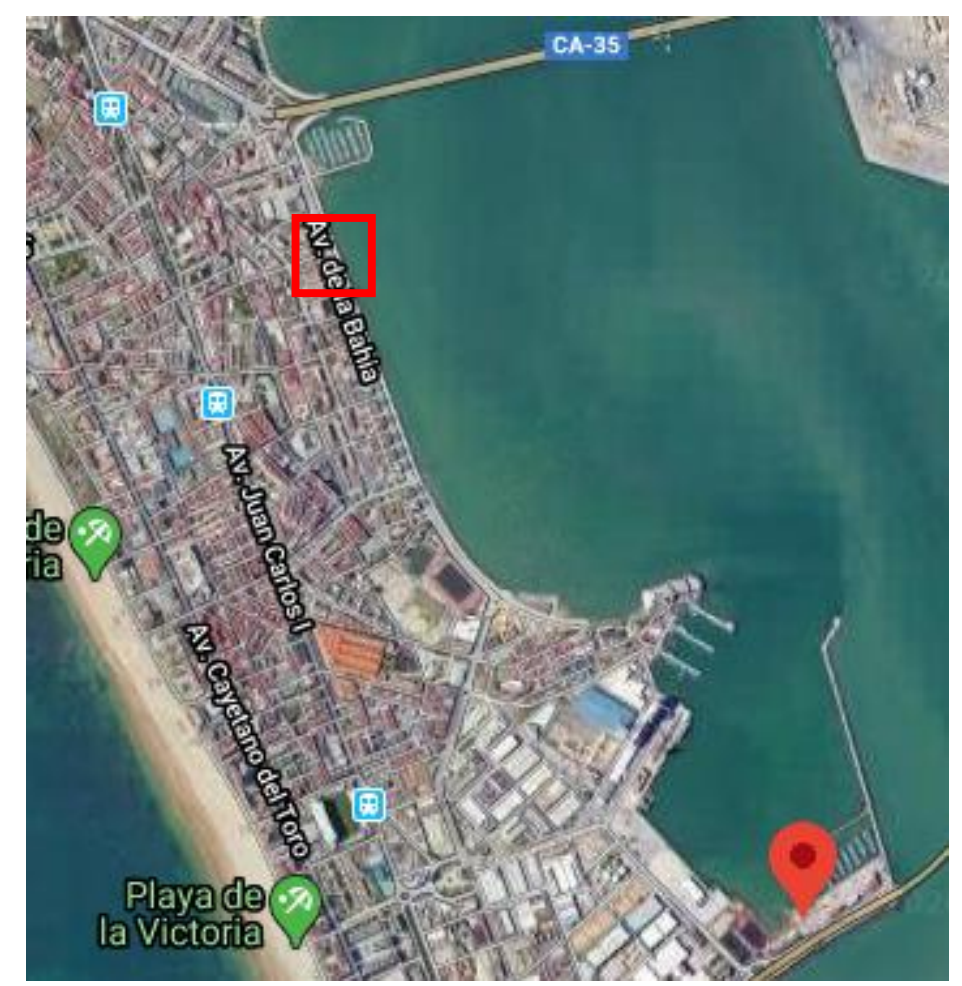

Figure 3. Location of the weather station (red point) and the case study (square). (Map data @2020 Instituto Geográfico Nacional, Google).

The period of record for Cadiz is 46 years (1973-2019), but only 11 years were used to generate the weather file. Cadiz is characterized by a A3 climatic severity (Spanish National Climatic Zoning for Energy Savings, CTE DB-HE1), which supposes very mild winters and temperate summers [55]. Cadiz is defined as a climate type "Csa" (Mediterranean hot summer climate) according to the Köppen classification, which means that is a temperate climate.

The maximum temperature for summer is $36.20^{\circ} \mathrm{C}$ (extreme summer week), with $22.90{ }^{\circ} \mathrm{C}$ being the average temperature for summer (typical summer week). The minimum temperature for winter is $5.40{ }^{\circ} \mathrm{C}$ (extreme winter week), with $13.18^{\circ} \mathrm{C}$ being the average temperature for winter (typical winter week). The average temperature during mid-seasons is around $17^{\circ} \mathrm{C}$. For a base temperature of $18^{\circ} \mathrm{C}$, the climate data give 803 annual heating degree-days (HDD) and 628 annual cooling degree-days (CDD).

According to the Universal Thermal Climate Index (UTCI), $72.37 \%$ of the annual hours are classified as Comfort hours (no thermal Heat Stress), followed by $19.63 \%$ annual Slight Cold Stress hours, $5.21 \%$ annual Moderate Cold Stress hours, $1.78 \%$ annual Slight Heat Stress hours, $0.50 \%$ annual Moderate Heat Stress hours, $0.31 \%$ annual Strong Cold Stress hours, and $0.19 \%$ annual Strong Heat Stress hours. 
The estimated sunshine hours per year are 1644, providing a maximum Direct Normal Solar Radiation of $8038 \mathrm{Wh} / \mathrm{m}^{2}$. The average Direct Normal Solar Radiation ranges from $2997 \mathrm{Wh} / \mathrm{m}^{2}$ in December to $5974 \mathrm{Wh} / \mathrm{m}^{2}$ in July; the average Diffuse Horizontal Solar Radiation ranges from $1036 \mathrm{Wh} / \mathrm{m}^{2}$ in December to $2911 \mathrm{Wh} / \mathrm{m}^{2}$ in June; and the average Global Horizontal Solar Radiation ranges from $2263 \mathrm{Wh} / \mathrm{m}^{2}$ in December to $7238 \mathrm{Wh} / \mathrm{m}^{2}$ in July.

The daily average daylight hours range from $9.7 \mathrm{~h}$ in December to $14.6 \mathrm{~h}$ in June. The average Direct Normal Illuminance ranges from $168 \mathrm{kLux}$ in December to $391 \mathrm{kLux}$ in July; the average Diffuse Horizontal Illuminance ranges from $117 \mathrm{kLux}$ in December to $340 \mathrm{kLux}$ in June; and the average Global Horizontal Illuminance ranges from $257 \mathrm{kLux}$ in December to $856 \mathrm{kLux}$ in July.

\subsubsection{Building Monitoring Campaign}

Not all the tenants gave agreement for installing sensors for the monitoring campaign, so, only 17 dwellings were monitored, representing $74 \%$ of the total number of 23 (Figure 4). Almost half of the monitored dwellings ( $8 / 47 \%$ ) have no equipment for air conditioning, 6 of them (35\%) have electric heaters (Joule effect), and 3 of them (18\%) have a heat pump for heating and cooling.

Each dwelling was equipped with hydrothermal sensors ( 8 of them with 3 sensors and 9 of them with 2 sensors) and an electric power meter. Due to difficulties on the installation of the electric power meters, the energy consumption data ranges from 1 October 2015 until 24 June 2016. Adding to this, 5 external sensors were installed at first floor ( 2 external sensors exposed to solar radiation and wind), third floor (1 external sensor exposed to wind), fourth floor (1 external sensor exposed to wind), and fifth floor (1 sensor exposed to wind).

\section{WS}

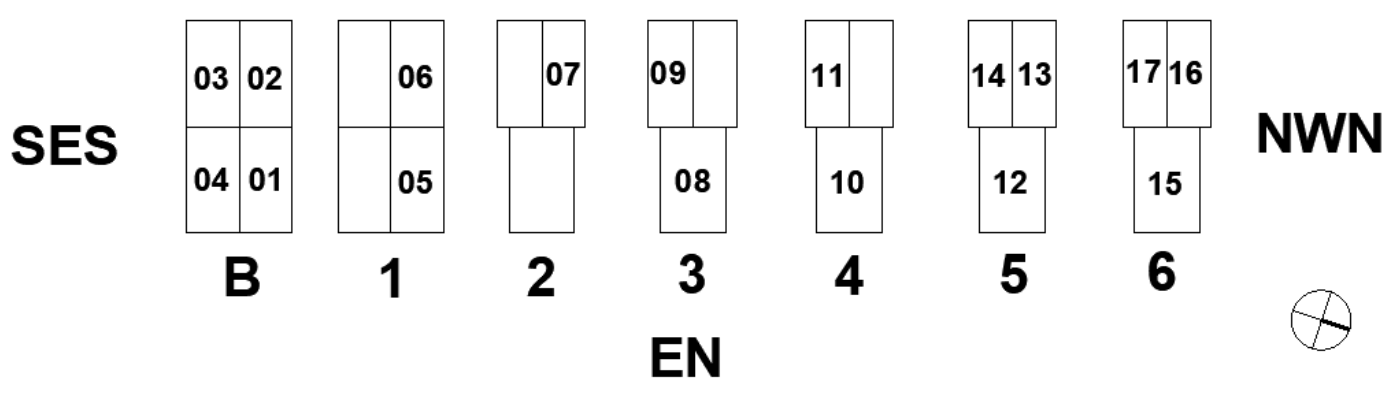

Figure 4. Monitored dwellings.

\subsubsection{Energy Demand Analysis Parameters}

The following parameters are defined for the analytical model in order to perform an energy simulation using the feature "Systems Analysis":

1. Building Type: Multi-familiar.

2. Location: Cádiz, Andalusia, Spain.

3. Ground Plane-Surfaces below this level are considered to be underground: Zero.

4. Building Construction-specifies the default type of construction for each element of the envelope, defined by its U-value and its solar heat gain coefficient for windows. The following constructions' elements are selected in order to be the most similar to the defined ones in the project:
a. Roof: $\mathrm{U}=0.5363 \mathrm{~W} / \mathrm{m}^{2} \cdot \mathrm{K}$.
b. Exterior walls: $\mathrm{U}=0.5601 \mathrm{~W} / \mathrm{m}^{2} \cdot \mathrm{K}$.
c. Interior walls: $\mathrm{U}=1.6896 \mathrm{~W} / \mathrm{m}^{2} \cdot \mathrm{K}$.
d. Ceilings: $\mathrm{U}=1.3683 \mathrm{~W} / \mathrm{m}^{2} \cdot \mathrm{K}$.
e. Floors: $\mathrm{U}=2.9582 \mathrm{~W} / \mathrm{m}^{2} \cdot \mathrm{K}$. 
f. Exterior windows: $\mathrm{U}=5.9050 \mathrm{~W} / \mathrm{m}^{2} \cdot \mathrm{K}, \mathrm{SHGC}=0.86$.

5. Building Infiltration Class-specifies an estimate of outdoor air that enters the building through leaks in the building envelope. The infiltration class has been defined as Medium, which represents an air infiltration of $0.19 \mathrm{~L} / \mathrm{s}^{2}$.

For each dwelling, the following parameters are defined:

1. Space properties:

a. Condition Type: Determines how heating and cooling loads are calculated. When set to Unconditioned, no loads are calculated. As when set to Heated, only heating loads are calculated. All the spaces are defined as Heated and Cooled in order to get the heating and cooling energy demand.

b. Space Type: Determines the internal loads associated to a certain activity. These values are defined according to the default operational conditions for private residential buildings defined for the Spanish Energy Rating Scheme [56].

i. Occupancy.

1. People $\left(\mathrm{n}^{\mathrm{o}}\right)$ : Data taken from monitoring data for each dwelling.

2. People Sensible Heat Gain (W/person): 73.27.

3. People Latent Heat Gain (W/person): 45.43.

4. Occupancy Schedule: Residential (100\% from 0:00 h, $25 \%$ from 7:00 h, 50\% from 15:00 $\mathrm{h}$, and $100 \%$ from 23:00 $\mathrm{h}$ ).

ii. Lighting.

1. Lighting Load Density $\left(\mathrm{W} / \mathrm{m}^{2}\right): 4.40$.

2. Lighting Schedule: Residential Lighting All Day (10\% from 0:00 h, 30\% from 7:00 h, 50\% from 18:00 h, 100\% from 19:00 h and 50\% from 23:00 h).

iii. Power equipment.

1. Power Load Density $\left(\mathrm{W} / \mathrm{m}^{2}\right): 4.40$.

2. Power Schedule: Residential Power All Day (10\% from 0:00 h, 30\% from 7:00 h, $50 \%$ from $18: 00 \mathrm{~h}, 100 \%$ from $19: 00 \mathrm{~h}$ and $50 \%$ from $23: 00 \mathrm{~h}$ ).

iv. Outdoor air.

1. Infiltration Flow $\left(\mathrm{L} / \mathrm{s} \mathrm{m}^{2}\right): 0.19$.

2. Outdoor air method: Defines the calculation method for outdoor air demand in a space. It is defined as by $\mathrm{ACH}$.

3. Air change per hour (ach/h): 0.63 .

2. Zone.

a. Building Service-specifies the type of heating and cooling system: Radiant heater or split system with natural ventilation according to monitoring information.

b. Cooling settings.

i. Cooling Set Point. Temperature at which the system will maintain the cooling in all spaces in the zone: $25^{\circ} \mathrm{C}$ according to the Spanish Energy Rating Scheme.

ii. Cooling Air Temperature. Supply air temperature used to cool all spaces in the zone: $12{ }^{\circ} \mathrm{C}$. 
c. Heating settings.

i. Heating Set Point. Temperature at which the system will maintain the cooling in all spaces in the zone: $20^{\circ} \mathrm{C}$ according to the Spanish Energy Rating Scheme.

ii. Heating Air Temperature. Supply air temperature used to cool all spaces in the zone: $32{ }^{\circ} \mathrm{C}$.

The surrounded buildings were modelled as conceptual masses in Revit. An opaque surface was assigned to the perimetral surfaces of these masses in order to be taken into account in the energy and lighting simulations as they block the solar access (entrance of solar heat gains and direct sunlight). The analysis mode selected in the energy settings dialog is "Use Conceptual Masses and Building Elements".

Revit does not have an architectural element category for shading, and as it can be read, no schedule expressing the movement and the window coverage of blinds can be introduced. By default, the energy analysis tool inside Revit considers that windows have no blinds.

\subsubsection{Daylighting Parameters}

For daylighting simulation, the following parameters are considered:

1. Surrounding buildings: Defined by conceptual masses with perimetral opaque surfaces.

2. Window transparency or visible transmittance: 0.90 .

3. Indoor surface reflectance: Floor $=0.50$; walls $=0.80$; ceiling $=0.95$.

The performance of blinds cannot be personalized. The blinds are considered by activating the option "Automated shades" as a property of the room. This means the blinds are automatically lowered to block high levels of direct solar and raised when not needed. This option was not activated because having no blinds implies to consider the daylighting potential and it is in concordance with the energy model.

\subsubsection{Solar Access Parameters}

The following time ranges were used to perform the solar access study: For winter solstice, the Sun Path diagram gives that the sun rises at around $10 \mathrm{~h}$ and the sunset is at around $19 \mathrm{~h}$; in the autumn equinox, the sun rises at around $8 \mathrm{~h}$ and the sunset is at around $20 \mathrm{~h}$, with the sunlight hours being the same as the spring equinox; finally for the summer solstice, the sun rises at around $7 \mathrm{~h}$ and the sunset is at around $22 \mathrm{~h}$.

Surrounding buildings are taken into account by assigning an opaque wall to their perimetral surfaces.

\section{Results}

In order to propose and assess the alternatives to a conventional refurbishment of an existing social housing, the first step is to analyze the state of the building previous to the intervention with the conventional solution.

The analysis takes the monitored data before the intervention in order to know whether the interior environmental conditions fall into the range of thermal comfort conditions. The BIM model is also simulated in order to get its energy performance, its daylighting conditions, and its solar exposure. The results coming from the Energy Certification model are used to rate the building according to the Spanish classification.

Refurbishment proposals are then exposed. The first proposal corresponds to the conventional solution implemented in the building and the other is an alternative to the original proposal considering the initial state of the building, the monitored data, and the analysis performed. 
The proposals are analyzed in order to get their energy, daylighting, solar exposure, and life cycle impact. The results of each analysis are exposed and compared in order to assess the adequacy of the proposals to the energy and environmental challenges.

\subsection{Original State}

The monitored data ranging from 21 November 2014 to 21 January 2015, the moment when the thermal insulation was installed, can be considered to reflect the environmental performance of the dwellings at their original construction stage. Figure 5 shows the temperature and relative humidity recorded data for the monitored dwellings without air conditioning equipment until 21 January 2015 as a dispersion graph where thermal comfort and permissible thermal comfort zones are from the Givoni's bioclimatic chart.

It can be seen how, in the main part of the monitored time, the indoor environmental conditions fall outside the thermal comfort zone and outside the permissible comfort zone, which considers the adaptive comfort due to the users' actions. The indoor winter conditions present a high relative humidity with low temperatures, so there is a need to increase the thermal insulation and the air changes in order to increase the indoor temperature, which will reduce the relative humidity, due to air renovation.

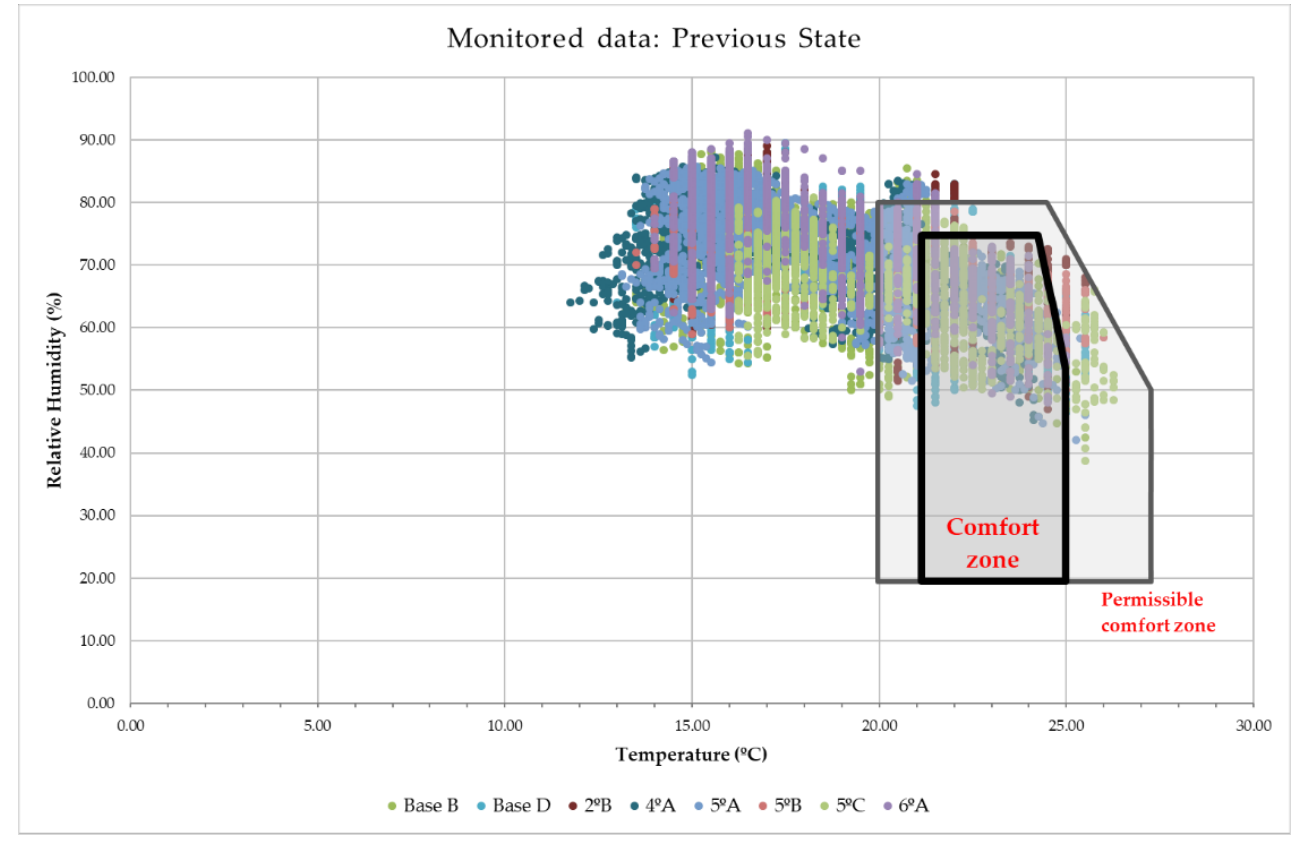

Figure 5. Temperature and relative humidity monitored data before the refurbishment works.

The measured data showed that dwellings NWN-EN-SES oriented (fourth to sixth A) are the coldest as the measured temperatures range from $11.75{ }^{\circ} \mathrm{C}$ to $25.50^{\circ} \mathrm{C}$, and the warmest is the SES-WS oriented (fifth C). This dwelling presents the higher percentage of temperature measurements within the comfort zone, being $32 \%$, and the fourth A presents the lower percentage of temperature measurements within the comfort zone, being $13.35 \%$. The NWN-EN-SES dwellings also present the lower median percentage of temperature measurements within the comfort zone $(13.82 \%)$, but these dwellings have the higher vertical wall surface exposed to outdoor conditions.

\subsubsection{Energy Demand Analysis}

The heating and cooling energy demand resulting from the Energy Rating model are $56.00 \mathrm{KWh} / \mathrm{m}^{2}$ year and $10.50 \mathrm{KWh} / \mathrm{m}^{2}$ year, respectively, obtaining a $\mathrm{G}$ and $\mathrm{C}$ level at the Spanish 
Energy Rating scheme. These results highlight the need for an energy refurbishment proposal based on thermal insulation in order to reduce mainly the heating energy demand.

The energy simulation in EnergyPlus for the original state of the building provides an annual sensible heat gain report giving detailed information about the heating and cooling annual energy demand and peak cooling and heating loads for each zone and the contribution to it of the different elements of the building. The values of heating and cooling energy demand are $49.02 \mathrm{KWh} / \mathrm{m}^{2}$ year and $38.57 \mathrm{KWh} / \mathrm{m}^{2}$ year, respectively. They differ from the obtained under the energy rating software, due to the constraints of both models regarding the blinds and how the energy rating model give the results, but heating energy demand prevails over cooling energy demand.

The peak heating sensible heat gain of the building occurs at 9:00 $\mathrm{h}$ on 20 January and the peak cooling sensible heat gain occurs at 18:15 h on 24 July. Figure 6 shows the contribution of each component to the peak sensible heat gain for both conditions.

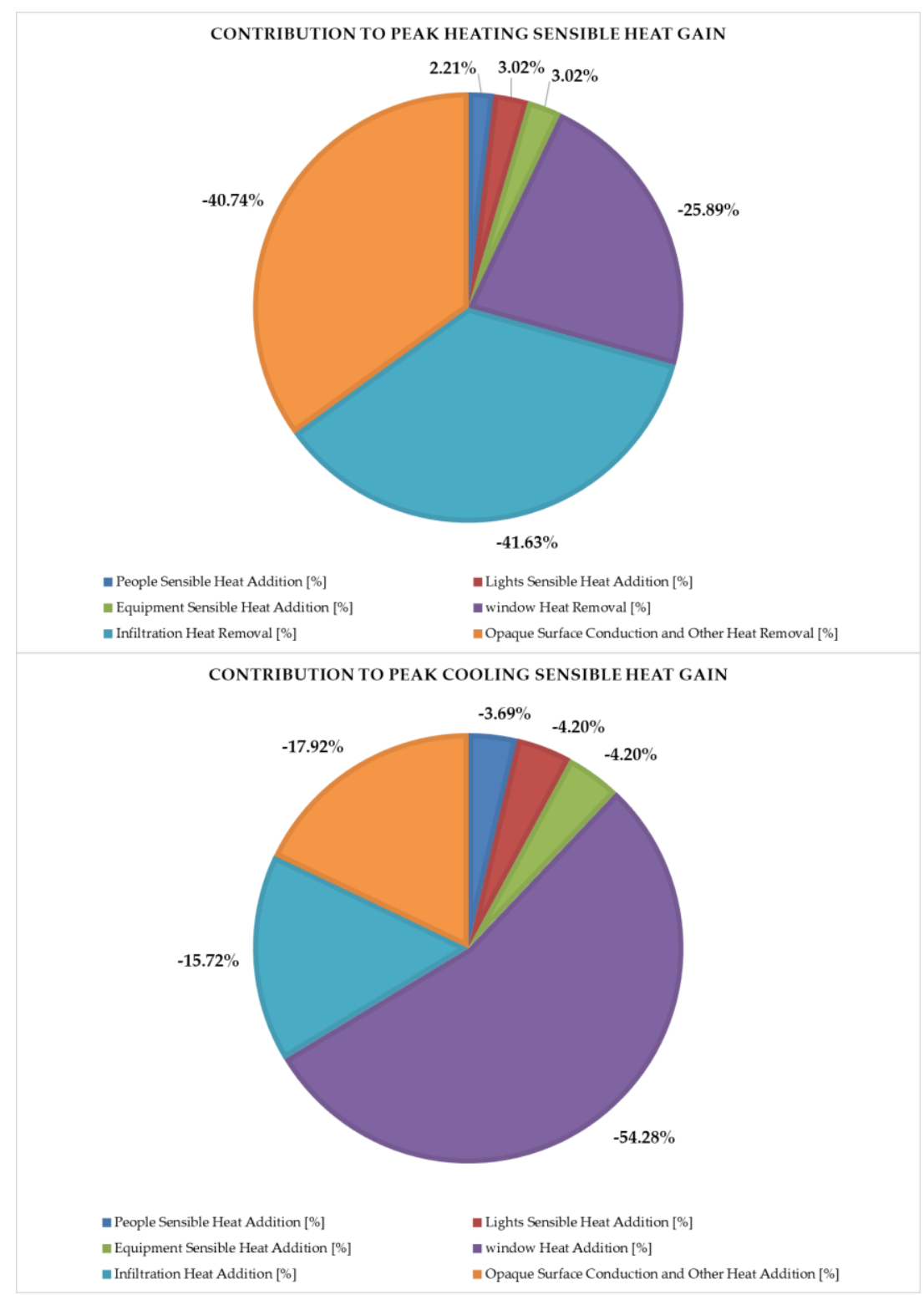

Figure 6. Contribution of each component to peak heating and cooling sensible heat gain at building level. 
The three main components contributing to heating loads are opaque surfaces, windows, and outdoor air infiltration, giving sensible heat outputs (negative values) that represent $40.74 \%$, $25.89 \%$, and $41.63 \%$, respectively. However, for cooling loads, the main contributing component are windows, representing $54.28 \%$ of the peak cooling load.

The dwellings presenting the higher heating energy demand are the dwellings of the base floor, followed by those with an NWN-EN-SES orientation and the first-floor dwellings. The base floor dwellings present the higher energy losses due to thermal conduction through opaque surfaces (around $65 \%$ of the energy balance) that come from the thermal transfer of walls and floors. The median contribution of the opaque surfaces in the NWN-EN-SES dwellings is $27.98 \%$, but they present the higher values of energy losses through windows (the median value is $32.54 \%$ ), being higher at the upper levels (46.88\% for sixth A and $42.60 \%$ for fifth A).

The dwellings presenting the higher cooling energy demand are also the base floor dwellings, followed by those dwellings with SES orientation; the other dwellings present similar cooling energy demand. As expected, dwellings with SES façade are those that present the higher energy gains through windows, presenting the SES-WS (letter C) dwellings the higher values. Accordingly, those of these dwellings with higher window surface have the highest energy gains.

Based on these results, the refurbishment proposals should focus on thermal insulation and more insulated windows, in order to reduce the heat losses, and solar protection, in order to reduce the gains through windows. Although outdoor air infiltration has similar weight as conduction through opaque surfaces, it cannot be changed due to normative requirements.

\subsubsection{Daylighting and Solar Exposure Analysis}

The following figures (Figures 7-10) show the distribution on the workplane of the calculated spatial Daylight Autonomy (\% hours) and the solar access (hours of direct sunlight) for winter solstice, autumn equinox, and summer solstice.
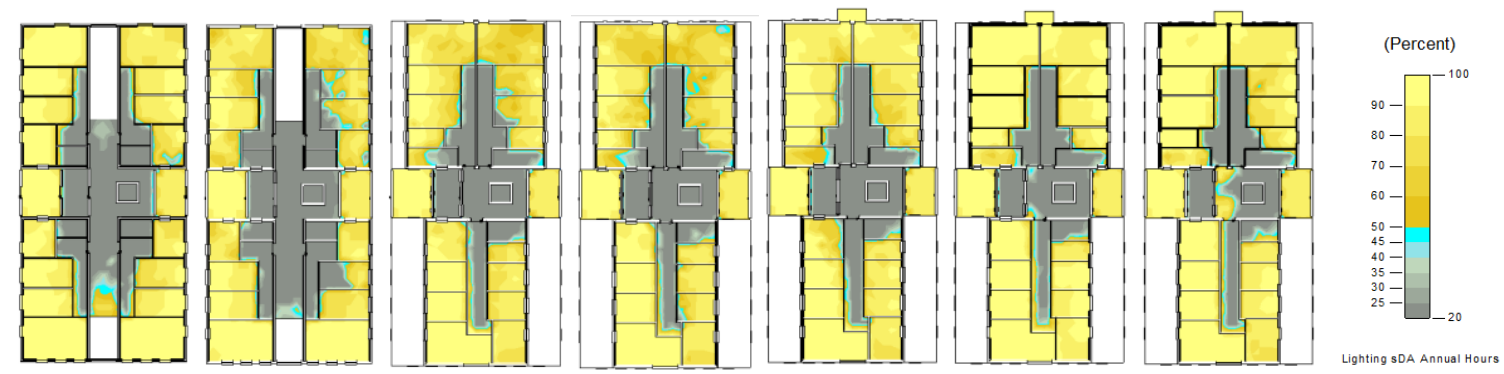

Figure 7. Spatial daylight autonomy (\% hours) distribution at the initial stage, from base to sixth floor.

The results of the daylighting study show that at least $55 \%$ of the workplane area of each dwelling receives 300 lux of natural light during 1825 annual hours, and only $69 \%$ of the dwellings meet the sDA \%hours for $75 \%$ of their workplane area. The dwellings that have near or more than $20 \%$ of their workplane area receiving direct sunlight illuminance equal or higher than 1000 lux for more than $250 \mathrm{~h}$ per year are those South-East-South oriented, so their openings should reduce their visual transparency.

Considering these results and both climate-based daylight metrics, the percentage of building area meeting sDA \%hours and ASE \%area is 70. 


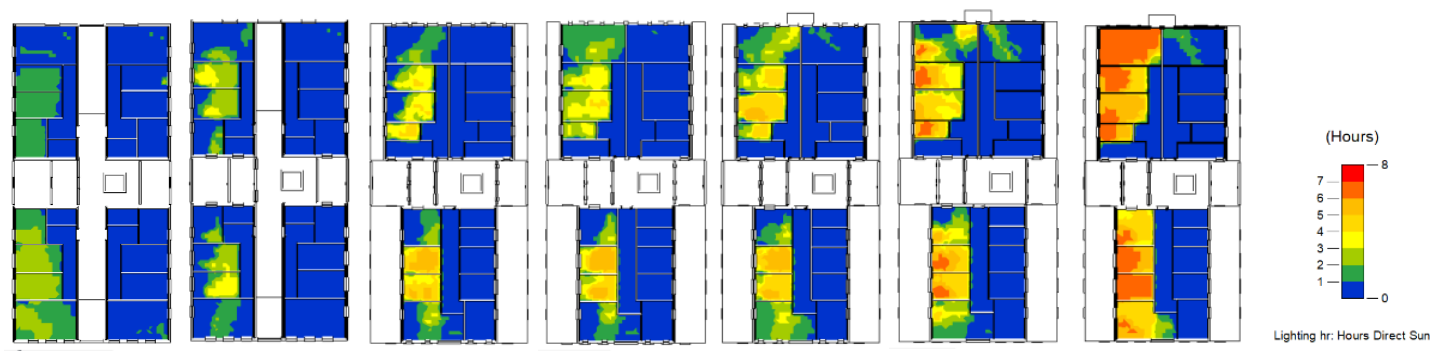

Figure 8. Solar exposure analysis (hours of direct sunlight) distribution at the initial stage for the winter solstice, from base to 6 th floor.

It can be seen how the highest number of hours of direct sunlight occurs at the sixth floor, with a maximum of $6 \mathrm{~h}$, and the minimum, as expected, occurs at the lower levels of the building. In these floors, the discrepancy of the uniformity is due to the variation of windows size. The window-to-wall ratio is higher at the base floor as it can be seen in Table 1 and Figure 2.

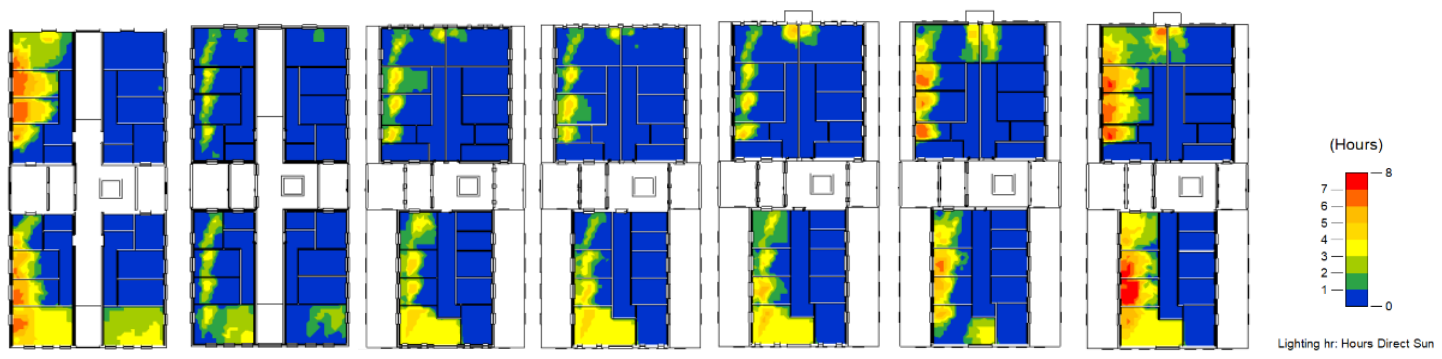

Figure 9. Solar exposure analysis (hours of direct sunlight) distribution at the initial stage for the autumn equinox, from base to sixth floor.

During autumn equinox, the sun rises at eastern position allowing the entrance of direct sunlight through the East-North façade. In this case, the maximum number of hours of direct sunlight is 8 and is achieved at the sixth floor, decreasing as going down the levels of the building due to the presence of surrounding buildings and the smaller size of windows, except for the base floor where window size is higher than for the upper levels (first to fourth).
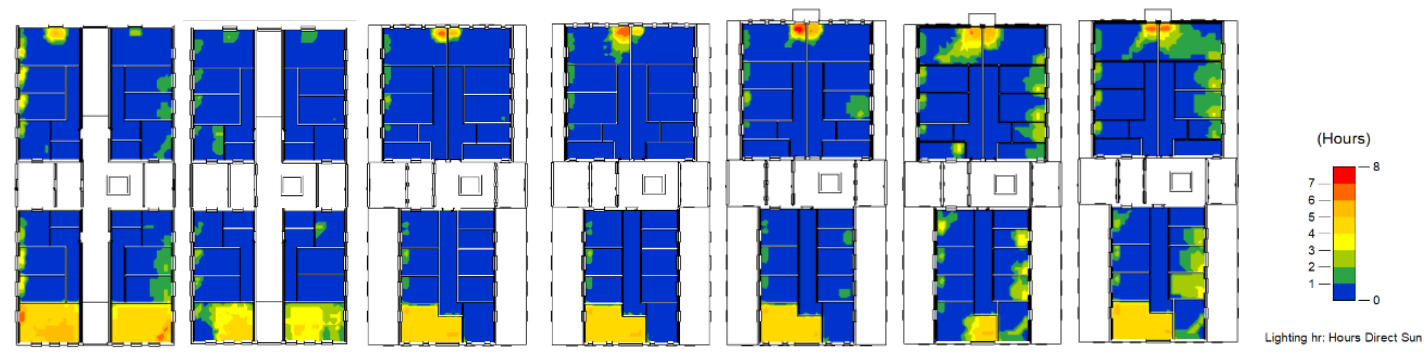

Figure 10. Solar exposure analysis (hours of direct sunlight) distribution at the initial stage for the summer solstice, from base to sixth floor.

Finally, during summer solstice, the northern sunrise position of the sun provides direct sunlight even through the North-West-North façade. The sunlight penetration is lower than autumn equinox due to the sun elevation, achieving the highest hours of direct sunlight near to the East-North and West-South openings. In this façade, the presence of the balconies reduces the sunlight penetration through the below windows. 


\subsection{Refurbishment Proposals}

The objective of the refurbishment is to recover the functionality of the building improving its energy performance and thermal comfort conditions without spatial transformation and minimizing physical actions.

\subsubsection{Original Proposal (P0)}

According to the energy rating results, the original proposal focused on roof, façades, and windows. The proposal consists on an incorporation of an EIFS (external insulation finishing system) on façades, roof renovation, and windows replacement.

The EIFS is composed by an insulation panel of EPS $(4 \mathrm{~cm})$ finished with an acrylic mortar. The new transmittance is $0.344 \mathrm{~W} /\left(\mathrm{m}^{2} \mathrm{~K}\right)$, which represents a reduction of $38.43 \%$. The roof renovation consisted of substituting the original slope formation based on simple hollow brick partitions leaving air between them for a cellular concrete slope formation and substitution of the original $4 \mathrm{~cm}$ of XPS thermal insulation for $6 \mathrm{~cm}$ of the same material. The new transmittance is $0.39 \mathrm{~W} /\left(\mathrm{m}^{2} \mathrm{~K}\right)$, which represents a reduction of $25.85 \%$. Original windows were substituted by other ones having a window frame with thermal break higher than $12 \mathrm{~mm}$ and double glazing $(4+6+4)$. The new transmittances are $3.20 \mathrm{~W} /\left(\mathrm{m}^{2} \mathrm{~K}\right)$ and $3.30 \mathrm{~W} /\left(\mathrm{m}^{2} \mathrm{~K}\right)$ respectively, representing a reduction of $44.83 \%$ and $43.10 \%$, respectively. The airtightness of the new windows is Class 2, according to UNE 12207:2017 about air permeability of windows and doors. The new solar heat gain coefficient of the glazing is 0.76 ( $10.59 \%$ reduction) and the visual transmittance is 0.81 ( $10 \%$ reduction).

It has to be highlighted that the new transmittances are beyond the minimum requirements of the last updated Spanish Energy Saving Regulatory Document for buildings [55] as can be seen in the following Table 3.

Table 3. U-values at initial and refurbished stages and current minimum requirement.

\begin{tabular}{|c|c|c|c|c|}
\hline $\begin{array}{c}\text { Envelope } \\
\text { Component }\end{array}$ & $\begin{array}{l}\text { Initial U-Value } \\
\left(\mathrm{W} / \mathrm{m}^{2} \mathrm{~K}\right)\end{array}$ & $\begin{array}{l}\text { P0 U-Value } \\
\left.\text { (W/m² }{ }^{2}\right)\end{array}$ & \% Improve & $\begin{array}{c}\min U-\text { Value } \\
\text { Requirement }\left(W / \mathrm{m}^{2} \mathrm{~K}\right)\end{array}$ \\
\hline Roof & 0.53 & 0.39 & $25.85 \%$ & 0.50 \\
\hline Walls & 0.56 & 0.34 & $38.43 \%$ & 0.70 \\
\hline Windows & 5.80 & 3.20 & $44.83 \%$ & 2.70 \\
\hline
\end{tabular}

\section{Monitored Data}

The monitored data ranging from 21 March 2015, the moment when the refurbishment works finished, to 10 May 2016, can be considered to reflect the environmental performance of the dwellings after the refurbishment works. Figure 11 shows the temperature and relative humidity recorded data for the monitored dwelling without air conditioning equipment during the monitored mentioned period as a dispersion graph where thermal comfort and permissible thermal comfort zones are from the Givoni's bioclimatic chart.

Compared to the monitored data from the original stage, the indoor temperature during the cold season increased almost a degree $\left(+0.96^{\circ} \mathrm{C}\right)$ and the relative humidity was reduced $0.74 \%$. The average monitored temperature during June, July, August, and September was $26.2^{\circ} \mathrm{C}$ and $18.59^{\circ} \mathrm{C}$ during December, January, and February, with the average annual indoor temperature being $22^{\circ} \mathrm{C}$. The relative humidity remains high throughout the monitored year that responds to the ambient humidity of the coastal location and the air change of the dwellings. 


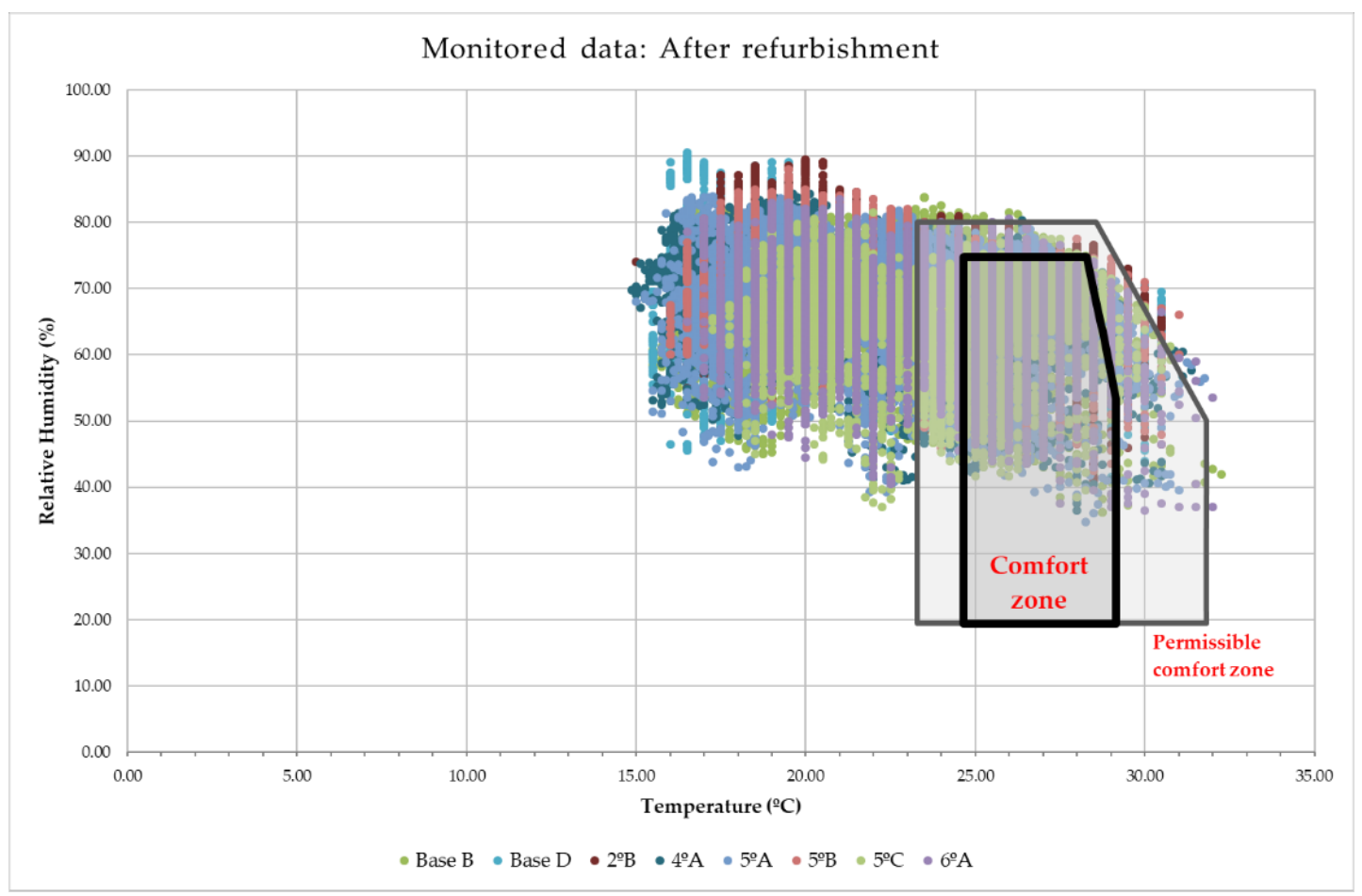

Figure 11. Temperature and relative humidity monitored data after the refurbishment works (21 March 2015-10 May 2016).

The measured data show that dwellings NWN-EN-SES oriented (fourth to sixth A) are still the coldest ones but after the refurbishment, the minimum measured temperature was $14.88^{\circ} \mathrm{C}$ in fourth A instead of $11.75^{\circ} \mathrm{C}$. The minimum difference between the minimum temperature before and after the intervention can be found in second B with an improvement of $0.50{ }^{\circ} \mathrm{C}$. After the refurbishment, dwellings are dryer. The minimum and maximum measured relative humidity present lower values, especially under the roofs. Although measurements after the intervention not only cover a winter period, the range of percentage of temperature measurements within the comfort zone is $18.83-35.28 \%$, so there is a relative low difference respect to the initial stage (13.35-31.99\%). However, if the limits are the permissible comfort zone there is a higher difference respect to the initial stage $(22.20-41.41 \%)$ and the range of percentage is quite positive (43.36-74.18\%).

Considering that the average outdoor temperature was colder after the intervention, the thermal attenuation of the envelope is higher as the difference between outdoor and indoor temperature after the intervention is higher than the original stage. The indoor conditions of the building during the hot season falls mainly into the comfort and permissible comfort zone. The punctual monitored data outside these zones indicate that comfort can be achieved by incorporating evaporative cooling systems or dissipating heat by night ventilation, for example. However, the days falling outside the comfort or even permissible comfort zones are more than $10 \%$, especially during winter, so heating systems are needed to achieve desirable indoor conditions.

\section{Energy Demand Analysis}

The heating and cooling energy demand resulting from the updated Energy Rating model are $14.30 \mathrm{KWh} / \mathrm{m}^{2}$ year and $10.00 \mathrm{KWh} / \mathrm{m}^{2}$ year, respectively, obtaining a D and C level at the Spanish Energy Rating scheme. They represent an improvement of $75 \%$ and $5 \%$, respectively. It is especially notorious the improvement of the heating energy demand, from $56.00 \mathrm{KWh} / \mathrm{m}^{2}$ year to $14.30 \mathrm{KWh} / \mathrm{m}^{2}$ year, which means an ascending of three levels in the Spanish Energy Rating scheme. 
The heating and cooling energy demand resulting from the energy simulation are $36.23 \mathrm{KWh} / \mathrm{m}^{2}$ year and $37.34 \mathrm{KWh} / \mathrm{m}^{2}$ year, respectively, representing an improvement of $26.09 \%$ and $3.19 \%$, respectively. The difference with respect to the Energy Rating model remains but the results also show a higher improvement in the heating energy demand. As exposed in the methodology section, the used energy rating model parametrizes the building, compares them with a database with results coming from the general procedure, and gets the energy performance values. Furthermore, the general procedure considers that blinds cover 30\% of window surface. On the other hand, the EnergyPlus model considers blinds open all the time, which has a great impact on the cooling energy demand.

Comparing the peak heating and cooling heat gains before and after the refurbishment (Figure 12) it can be observed how the improvement of the heating energy demand is higher at the dwellings with higher surface of external walls (letter A, levels 2-6). Analyzing the improvement by levels, the average improvement of heating energy demand at Base level is around $10 \%$, being around $20 \%$ at levels 1 and 2, around 25\% at levels 3 and 4, and almost $27 \%$ at levels 5 and 6 .

The distribution of the weight of the heating and cooling energy demand by level or orientation remains as exposed during the energy demand analysis of the initial stage although the absolute values are lower due to the reduction of the thermal transmittance of opaque and window surfaces and the reduction of the solar heat gain coefficient of the windows.
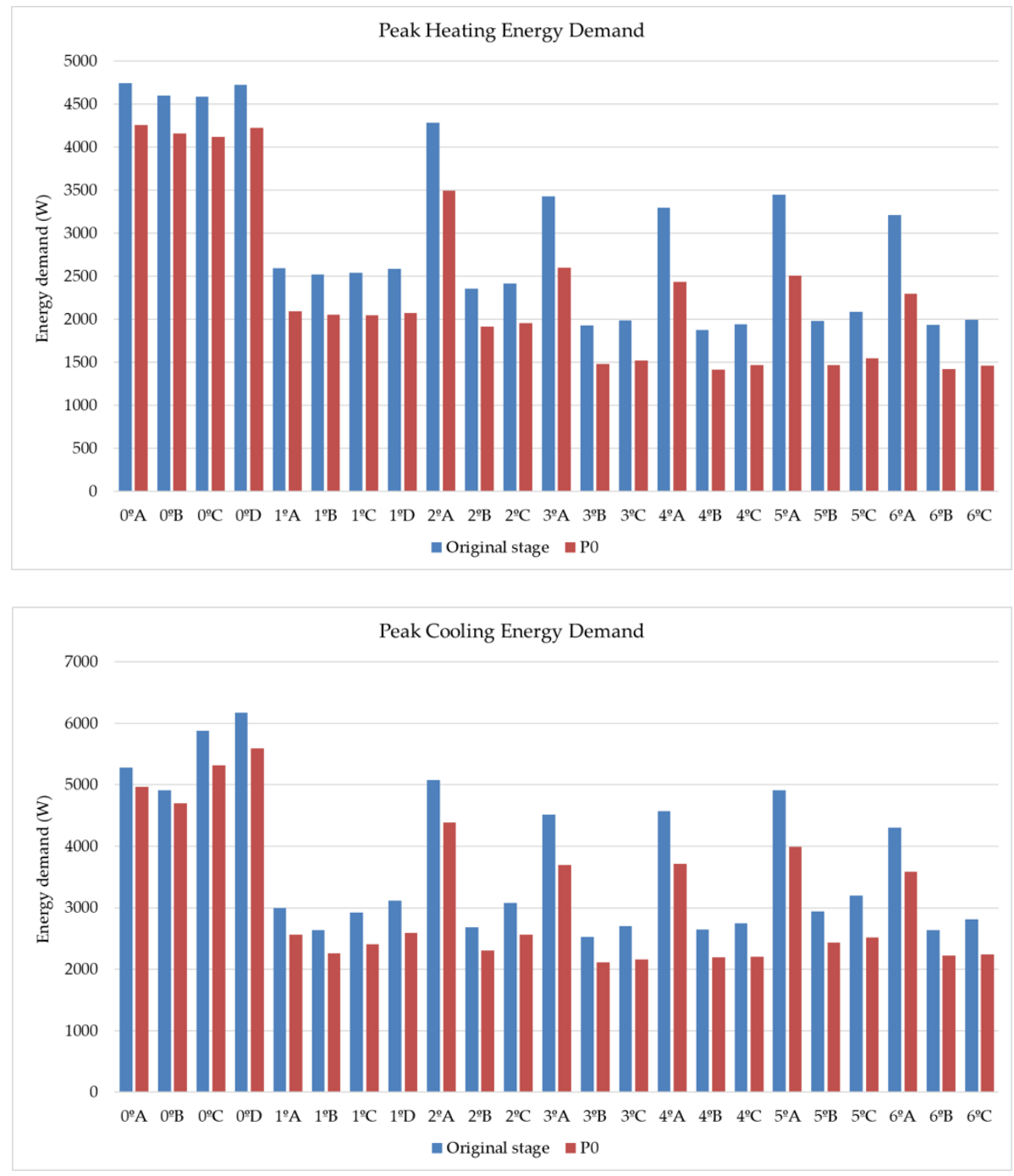

Figure 12. Comparison of peak heating and cooling energy demand for each dwelling. 
Regarding the improvement of cooling energy demand, except for the Base level where the improvement is around 7\%, the improvement of cooling energy demand is around $15 \%$ at levels 1 to 6 , being higher at dwellings South-East-South oriented, especially those of letter $C$, with an improvement of around $20 \%$, as the SES façade is their main outdoor walls.

\section{Daylighting and Solar Exposure Analysis}

As the original proposal changes the visual transmittance of glazing but does not incorporate solar protection components as overhangs, slats, or side fins, only a daylighting analysis is performed in order to know the effect of changing the transparency of glazing on visual comfort.

Figure 13 shows the results of spatial Daylight Autonomy (primary vertical axis) and Annual Sunlight Exposure (secondary vertical axis) before and after the refurbishment. Dashed lines mark the assessment criteria for sDA and dotted line marks the assessment criterion for ASE.

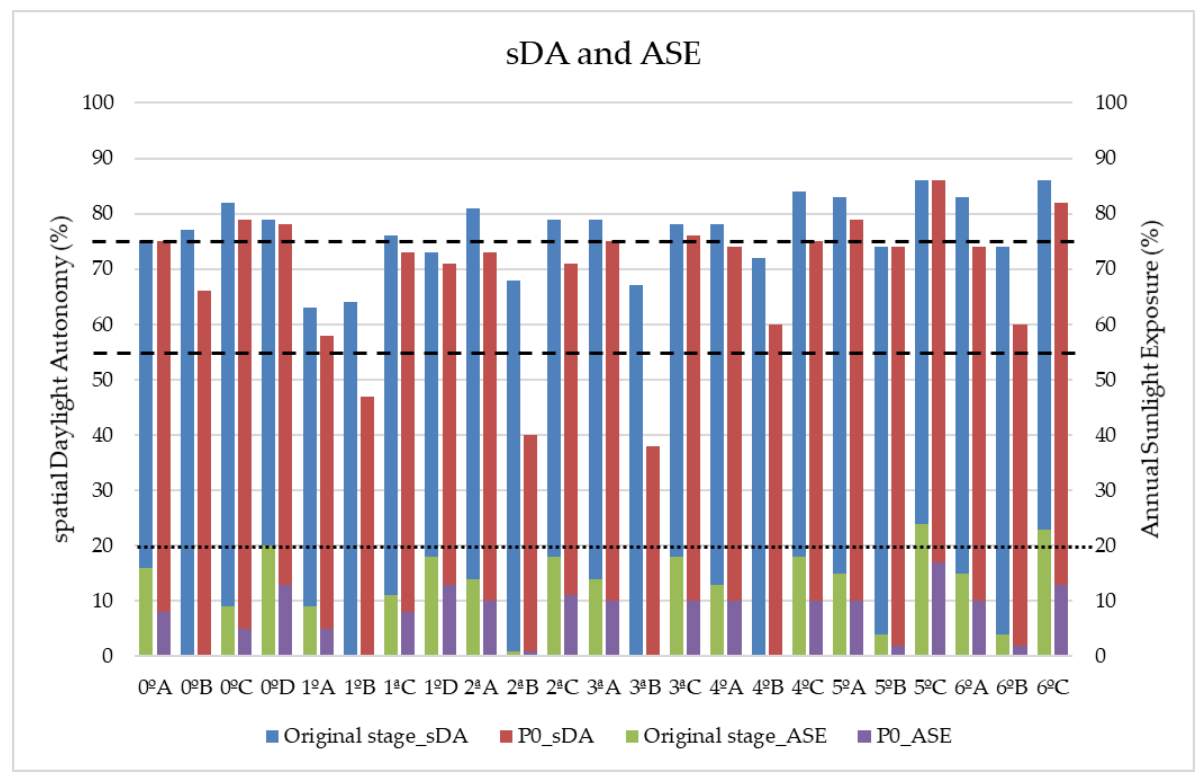

Figure 13. Comparison of spatial Daylight Autonomy and Annual Sunlight Exposure for each dwelling.

It can be seen how reducing the transparency of glazing reduces both sDA and ASE. The higher decrease of sDA can be found at dwellings North-West-North oriented, except for fifth B, with a minimum decrease of around $15 \%$ and a maximum decrease of around $43 \%$. In fact, none of the dwellings before the intervention has a sDA lower than $55 \%$ and after the refurbishment there are three dwellings that do not comply with the lowest sDA criterion. Before the intervention, there were 14 dwellings achieving the highest sDA criterion and after that only 6 dwellings have an sDA higher than $75 \%$.

However, the Annual Sunlight Exposure is also affected by the intervention but in a positive way. Before the windows substitution, there were two dwellings with an ASE higher than $20 \%$ that comply with the criterion after the refurbishment. The improvement of ASE ranges from $30 \%$ to $50 \%$.

It must to be highlighted that EnergyPlus and Radiance models consider blinds open all the time. This can benefit natural lighting until having excessive direct lighting, and can benefit solar heat gains in winter, but penalize the cooling demand in summer. The monitoring campaign show that the users are taking actions to keep their dwellings in the permissible comfort zone, thus they are probably lowering the blinds. This action lowers the daylighting indoor availability affecting visual comfort, but also reduces the entrance of solar heat gains allowing to achieve a bearable indoor temperature. 
Life Cycle Analysis

The life cycle analysis of the intervention considers the impact of the following materials:

1. Roof P0 $\left(282.17 \mathrm{~m}^{2}\right)$.

a. Lightweight structural concrete, $2501-3000 \mathrm{psi}, 0-19 \%$ fly ash $(80,669 \mathrm{~kg}$, durability: Building life).

b. Self-adhering sheet waterproofing, modified bituminous sheet $(1539 \mathrm{~kg}$, durability: Building life).

c. Extruded polystyrene (XPS) $(656.4 \mathrm{~kg}$, durability: 50 years).

d. Cement mortar (8766 kg, durability: 60 years).

e. $\quad$ Ceramic tile ( $2863 \mathrm{~kg}$, durability: 60 years).

2. Walls P0 (1092.82 $\left.\mathrm{m}^{2}\right)$.

a. Expanded polystyrene (EPS) (1834 kg, durability: 50 years).

b. Cement mortar $(86910 \mathrm{~kg}$, durability: 60 years).

3. Windows $\mathrm{P} 0\left(287.36 \mathrm{~m}^{2}\right)$.

a. Glazing, double pane IGU (6464.95 kg, durability: 40 years).

b. Window frame, aluminum, operable, thermal break $(1578.40 \mathrm{~kg}$, durability: 45 years, with an adequate disassembly the aluminum can be recycled).

Tables 4-6 show the environmental impacts of these materials by LCA stages per area (Table 4), category (Table 5), and the contribution of each building element and material to each environmental impact item (Table 6).

Table 4. Environmental impacts for each life cycle stage.

\begin{tabular}{|c|c|c|c|c|}
\hline $\begin{array}{l}\text { Environmental } \\
\text { Impacts/Area }\end{array}$ & $\begin{array}{l}\text { Product Stage } \\
\text { [A1-A3] }\end{array}$ & $\begin{array}{c}\text { Construction } \\
\text { Stage [A4] }\end{array}$ & Use Stage [B2-B5] & $\begin{array}{c}\text { End of Life Stage } \\
\text { [C2-C4] }\end{array}$ \\
\hline $\mathrm{GWP}\left(\mathrm{kgCO}_{2} \mathrm{eq} / \mathrm{m}^{2}\right)$ & 69.30 & 1.265 & 25.90 & 4.256 \\
\hline $\mathrm{AP}\left(\mathrm{kgSO}_{2} \mathrm{eq} / \mathrm{m}^{2}\right)$ & 0.2248 & 0.00586 & 0.1293 & 0.0207 \\
\hline $\mathrm{EP}\left(\mathrm{kgNeq} / \mathrm{m}^{2}\right)$ & 0.011 & $4.771 \times 10^{-4}$ & 0.006702 & 0.001542 \\
\hline $\mathrm{SFP}\left(\mathrm{kgO}_{3} \mathrm{eq} / \mathrm{m}^{2}\right)$ & 3.253 & 0.1936 & 1.815 & 0.3937 \\
\hline ODP (kgCFC-11eq/m²) & $9.879 \times 10^{-9}$ & $4.331 \times 10^{-14}$ & $1.034 \times 10^{-9}$ & $6.392 \times 10^{-12}$ \\
\hline $\operatorname{PED}\left(\mathrm{MJ} / \mathrm{m}^{2}\right)$ & 840.5 & 18.39 & 485.1 & 72.74 \\
\hline $\operatorname{NRED}\left(\mathrm{MJ} / \mathrm{m}^{2}\right)$ & 765.1 & 17.95 & 435.8 & 68.04 \\
\hline RED $\left(\mathrm{MJ} / \mathrm{m}^{2}\right)$ & 76.00 & 0.4447 & 49.65 & 4.769 \\
\hline
\end{tabular}

GWP = Global Warming Potential; AP = Acidification Potential; EP = Eutrophication Potential; SFP = Smog Formation Potential; ODP = Ozone Depletion Potential; $P E D=$ Primary Energy Demand; NRED = Non-Renewable Energy Demand; RED = Renewable Energy Demand.

It can be seen how the Product Stage [A1-A3] represent the higher contributor for each environmental impact, with a weight of around $60 \%$ for all items except for global warming potential (GWP) and ozone depletion potential (ODP), of which the weight is almost $70 \%$ and almost $90 \%$, respectively. The lower contributor is the Construction Stage [A4], ranging from almost null contribution for ODP to $3.42 \%$ for Smog Formation Potential (SFP).

The environmental impact by each category is shown in Table 5. It can be observed that the category "Openings and Glazing" is the main contributor to acidification, eutrophication, smog formation, primary energy demand, non-renewable energy demand, and renewable energy demand. The category "Finishes" is the main contributor to global warming impact, ozone depletion, and mass. However, the Concrete category is the lower contributor to ozone depletion, primary energy demand, and non-renewable energy demand, with Thermal and Moisture Protection being the lower contributor to acidification, eutrophication, global warming, smog formation, renewable energy demand, and mass. 
Table 5. Environmental impact potential for each category.

\begin{tabular}{|c|c|c|c|c|c|}
\hline & Concrete & $\begin{array}{c}\text { Thermal and } \\
\text { Moisture } \\
\text { Protection }\end{array}$ & $\begin{array}{l}\text { Openings and } \\
\text { Glazing }\end{array}$ & Finishes & Total General \\
\hline $\mathrm{GWP}\left(\mathrm{kgCO}_{2} \mathrm{eq}\right)$ & $23,074.53$ & $17,343.54$ & $42,402.30$ & $63,650.03$ & $146,470.40$ \\
\hline $\mathrm{AP}\left(\mathrm{kg} \mathrm{SO}_{2} \mathrm{eq}\right)$ & 96.82 & 37.23 & 247.39 & 284.59 & 666.03 \\
\hline EP (kg Neq) & 4.46 & 3.55 & 12.72 & 11.47 & 32.20 \\
\hline ODP (CFC-11eq) & $5.54 \times 10^{-9}$ & $6.02 \times 10^{-7}$ & $2.17 \times 10^{-6}$ & $1.34 \times 10^{-4}$ & $1.37 \times 10^{-4}$ \\
\hline $\mathrm{SFP}\left(\mathrm{kgO}_{3} \mathrm{eq}\right)$ & 1390.41 & 858.95 & 3048.84 & 4687.00 & 9985.19 \\
\hline PED (MJ) & $289,903.34$ & $515,964.91$ & $629,336.58$ & $726,795.01$ & $2,161,999.84$ \\
\hline NRED (MJ) & $258,614.11$ & $505,580.22$ & $571,342.73$ & $669,662.07$ & $2,005,199.13$ \\
\hline RED (MJ) & $31,398.96$ & $10,388.69$ & $59,432.54$ & $57,028.73$ & $158,248.91$ \\
\hline Mass (kg) & $80,404.84$ & 6519.31 & $16,045.01$ & $101,878.64$ & $204,847.81$ \\
\hline
\end{tabular}

GWP = Global Warming Potential; AP = Acidification Potential; EP = Eutrophication Potential; SFP = Smog Formation Potential; ODP = Ozone Depletion Potential; PED = Primary Energy Demand; NRED = Non-Renewable Energy Demand; RED = Renewable Energy Demand.

The contribution of each refurbished building element and material is shown in Table 6. Due to the higher area of intervention, walls have a higher impact on each environmental impact followed by windows. However, although the intervention on roofs covers the lower area, due to the substitution of the slope formation for lightweight concrete, the percentage of mass is similar to the employed in walls.

It has to be highlighted that although the surface of windows is $25 \%$ of the opaque surface of walls, the contribution of windows is very similar to the contribution of walls, indicating the high environmental impact of window materials.

Regarding the contribution of the materials, it can be seen how cement-based materials have high environmental impact, especially in the ozone depletion, in which they are almost the unique contributors. An eco-efficient intervention should, thus, look for an alternative to these materials that, in this case, are not used for structural elements.

The materials composing the windows have similar contribution in almost all the environmental impact items, but it should be taken into consideration that the surface of glazing is around $90 \%$ of the window, so this indicates the toxicity of the aluminum parts of the windows.

Table 6. Contribution of each material to the environmental impacts.

\begin{tabular}{cccccccccc}
\hline & $\begin{array}{c}\text { GWP } \\
\mathbf{( \% )}\end{array}$ & $\begin{array}{c}\text { AP } \\
\mathbf{( \% )}\end{array}$ & $\begin{array}{c}\text { EP } \\
\mathbf{( \% )}\end{array}$ & $\begin{array}{c}\text { ODP } \\
\mathbf{( \% )}\end{array}$ & $\begin{array}{c}\text { SFP } \\
\mathbf{( \% )}\end{array}$ & $\begin{array}{c}\text { PED } \\
\mathbf{( \% )}\end{array}$ & $\begin{array}{c}\text { NRED } \\
\mathbf{( \% )}\end{array}$ & $\begin{array}{c}\text { RED } \\
(\mathbf{\%})\end{array}$ & $\begin{array}{c}\text { Mass } \\
(\mathbf{\%})\end{array}$ \\
\hline Roofs & $\mathbf{2 3 . 1 2}$ & $\mathbf{2 4 . 9 8}$ & $\mathbf{2 8 . 5 7}$ & $\mathbf{9 . 6 9}$ & $\mathbf{2 4 . 2 6}$ & $\mathbf{2 6 . 8 1}$ & $\mathbf{2 6 . 5 4}$ & $\mathbf{3 0 . 2 6}$ & $\mathbf{4 6 . 6 5}$ \\
Ceramic tile & 0.33 & 0.40 & 0.65 & 0.00 & 0.47 & 0.76 & 0.78 & 0.60 & 1.40 \\
Cement grout & 0.25 & 0.19 & 0.26 & 0.69 & 0.25 & 0.18 & 0.17 & 0.29 & 0.27 \\
Cement mortar & 3.39 & 2.53 & 3.31 & 8.91 & 3.45 & 2.38 & 2.38 & 2.39 & 4.27 \\
XPS & 1.06 & 2.54 & 2.34 & 0.00 & 1.39 & 5.08 & 5.23 & 3.29 & 0.64 \\
bitumen & 0.71 & 0.94 & 0.84 & 0.08 & 0.76 & 2.24 & 2.34 & 0.89 & 0.75 \\
concrete & 17.38 & 18.37 & 21.18 & 0.01 & 17.94 & 16.17 & 15.65 & 22.80 & 39.33 \\
\hline Walls & $\mathbf{4 0 . 9 7}$ & $\mathbf{3 7 . 5 9}$ & $\mathbf{4 4 . 3 5}$ & $\mathbf{8 8 . 7 3}$ & $\mathbf{4 6 . 6 3}$ & $\mathbf{4 5 . 0 0}$ & $\mathbf{4 5 . 8 7}$ & $\mathbf{3 3 . 5 7}$ & $\mathbf{4 5 . 5 2}$ \\
Paint acrylic & 3.70 & 5.52 & 3.63 & 0.00 & 6.36 & 5.63 & 5.46 & 7.70 & 1.36 \\
Cement mortar & 33.62 & 25.11 & 32.81 & 88.36 & 34.22 & 23.59 & 23.56 & 23.73 & 42.37 \\
EPS & 3.64 & 6.96 & 7.91 & 0.36 & 6.05 & 15.78 & 16.85 & 2.14 \\
\hline Windows & $\mathbf{3 5 . 9 1}$ & $\mathbf{3 7 . 4 3}$ & $\mathbf{2 7 . 0 9}$ & $\mathbf{1 . 5 9}$ & $\mathbf{2 9 . 1 1}$ & $\mathbf{2 8 . 1 8}$ & $\mathbf{2 7}$ & 1.79 \\
Glazing & 20.91 & 18.33 & 11.86 & 0.01 & 17.52 & 11.99 & 12.32 & $\mathbf{3 6 . 1 7}$ & $\mathbf{7 . 8 2}$ \\
Hardware & 0.29 & 0.16 & 0.32 & 0.02 & 0.19 & 0.36 & 0.32 & 0.87 \\
alum & 14.70 & 18.94 & 14.91 & 1.56 & 11.40 & 15.83 & 14.95 & 27.18 & 6.30 \\
Frame alum & & &
\end{tabular}

GWP = Global Warming Potential; AP = Acidification Potential; EP = Eutrophication Potential; SFP = Smog Formation Potential; ODP = Ozone Depletion Potential; PED = Primary Energy Demand; NRED = Non-Renewable Energy Demand; RED = Renewable Energy Demand. 


\subsubsection{Alternative Proposal (P1)}

The alternative proposal substitutes the materials used in proposal P0 for other ones with lower environmental impact based on their Environmental Performance Declaration (EPD) when existing. The materials for proposal 1 were chosen based on the materials that can be found in the most common and available Spanish databases of environmental information of construction materials and products (BEDEC database [57] and Green Building Council España database [58]) as stakeholders that are interested in the incorporation of materials with an EPD but not being experts in this issue will look in them. Furthermore, if the materials are in those databases, they can be found in the current market so their cost would not be as high as looking for a special material or component. The materials of the first proposal are listed below indicating whether it is substituted and giving information of their Global Warming Potential, when there is an EPD, and their conductivity:

1. Roof P1 $\left(282.17 \mathrm{~m}^{2}\right)$.

a. Lightweight structural concrete, 2501-3000 psi, >50\% slag $(0.21 \mathrm{~W} / \mathrm{m} \mathrm{K}, 80,473 \mathrm{~kg}$, durability: Building life).

b. P0 modified bituminous sheet (not modified).

c. Woodfibre insulation board $220 \mathrm{~kg} / \mathrm{m}^{3}(0.047 \mathrm{~W} / \mathrm{m} \mathrm{K}, 5748.80 \mathrm{~kg}$, durability: 30 years, it can be used as renewable energy at the end of its life).

d. Cement mortar $7.01 \mathrm{kgCO} 2 \mathrm{eq} / \mathrm{m}^{2}(0.55 \mathrm{~W} / \mathrm{m} \mathrm{K}, 8774 \mathrm{~kg}$, durability: 60 years).

e. $\quad$ P0 Ceramic tile (not modified).

2. Walls P1 $\left(1092.82 \mathrm{~m}^{2}\right)$.

a. $\quad$ Cork panels $(0.040 \mathrm{~W} / \mathrm{m} \mathrm{K}, 34,406 \mathrm{~kg}$, durability: 25 years).

b. Cement mortar $3.61 \mathrm{kgCO} 2 \mathrm{eq} / \mathrm{m}^{2}(0.33 \mathrm{~W} / \mathrm{m} \mathrm{K}, 86,910 \mathrm{~kg}$, durability: Building life).

3. Windows P1: $122 \mathrm{kgCO}_{2} \mathrm{eq} / \mathrm{m}^{2}$ (maintained U-values, SHGC and transparency, $287.36 \mathrm{~m}^{2}$ ).

a. Glazing, double pane IGU (not modified).

b. Window frame, PVC, operable, thermal break (2702.51 kg, durability: 30 years).

The thickness of the materials composing Walls P1 and Roof P1 is modified in order to get the U-values of the P0 elements.

Table 7 shows the environmental impacts of each substituted material, at both proposals, and the summary of the environmental impacts of each refurbished envelope element.

It can be seen how the introduction of natural-based materials for insulation captures $\mathrm{CO}_{2}$ and CFCs giving a positive global balance in the Global Warming Potential and Ozone Depletion Potential. The use of wood-fiber insulation also reduces the Acidification Potential and the Smog Formation Potential but heavily increase the Energy Demand, especially the renewable one. The substitution of the EPS insulation for Cork Panel insulation increases the AP, EP, SFP, and EPD, although reduces the NRED.

Substituting the cement-based materials reduces all the environmental impacts and the use of eco-efficient PVC window frame instead of Aluminum also improves all the environmental impacts. However, the low recyclability of the PVC compared to the Aluminum must be considered [59]. 
Table 7. Comparison of the environmental impacts of each substituted material.

\begin{tabular}{|c|c|c|c|c|c|c|c|c|c|}
\hline & GWP & AP & EP & ODP & SFP & PED & NRED & RED & $\mathbf{M}$ \\
\hline \multicolumn{10}{|c|}{ Original proposal P0 } \\
\hline Roofs & $44,719.13$ & 159.31 & 8.49 & $1.33 \times 10^{-5}$ & 2540.94 & $598,800.46$ & $549,556.57$ & $49,725.19$ & $95,693.00$ \\
\hline Cement mortar & 5181.68 & 23.37 & 0.86 & $1.22 \times 10^{-5}$ & 361.52 & $53,131.74$ & $49,200.12$ & 3932.50 & 8766.17 \\
\hline XPS & 3656.26 & 7.29 & 0.86 & $1.67 \times 10^{-9}$ & 145.58 & $113,544.42$ & $108,196.19$ & 5402.00 & 1312.87 \\
\hline concrete & 33153.1 & 119.72 & 6.24 & $7.36 \times 10^{-9}$ & 1878.98 & $361,035.69$ & $323,997.06$ & 37471.4 & $80,668.53$ \\
\hline Walls & $69,427.54$ & 282.23 & 12.77 & $1.21 \times 10^{-4}$ & 4883.99 & $1,004,995.15$ & $949,682.78$ & $55,163.63$ & $93,373.48$ \\
\hline Cement mortar & $51,370.96$ & 231.65 & 8.53 & $1.21 \times 10^{-4}$ & 3584.06 & $526,745.71$ & $487,767.75$ & $38,986.66$ & $86,907.39$ \\
\hline EPS & $12,378.94$ & 25.07 & 2.36 & $4.92 \times 10^{-7}$ & 633.41 & $352,432.97$ & $348,861.60$ & 3523.55 & 3667.91 \\
\hline Windows & $42,402.30$ & 247.39 & 12.72 & $2.17 \times 10^{-6}$ & 3048.84 & $629,336.58$ & $571,342.73$ & $59,432.54$ & $16,045.01$ \\
\hline Alum frame & $23,345.56$ & 101.30 & 6.44 & $2.13 \times 10^{-6}$ & 1194.42 & $353,545.69$ & $309,474.77$ & $44,655.52$ & 2914.78 \\
\hline Total general & $156,548.97$ & 688.93 & 33.97 & $1.37 \times 10^{-4}$ & $10,473.76$ & $2,233,132.20$ & $2,070,582.08$ & $164,321.36$ & $205,111.50$ \\
\hline \multicolumn{10}{|c|}{ Proposal 1: Materials substitution } \\
\hline Roofs & $23,669.94$ & 141.48 & 6.84 & $-4.63 \times 10^{-4}$ & 2072.21 & $781,144.61$ & $569,819.87$ & $152,392.25$ & 139241.18 \\
\hline Cement mortar & 1978.01 & 8.92 & 0.33 & $4.65 \times 10^{-6}$ & 138.00 & $20,282.07$ & $18,781.24$ & 1501.16 & 8766.17 \\
\hline Woodfibre & -9725.84 & 1.58 & 0.59 & $-4.82 \times 10^{-4}$ & 0.08 & $342,339.93$ & $171,169.97$ & $112,132.52$ & $35,735.27$ \\
\hline concrete & $23,094.07$ & 96.90 & 4.47 & $5.54 \times 10^{-9}$ & 1391.59 & $290,148.80$ & $258,833.09$ & $31,425.54$ & $80,472.92$ \\
\hline Walls & $-89,837.66$ & 1105.66 & 230.42 & $9.31 \times 10^{-6}$ & $16,073.59$ & $806,211.93$ & $393,269.26$ & $412,329.34$ & $192,922.27$ \\
\hline Cement mortar & 3945.08 & 17.79 & 0.66 & $9.29 \times 10^{-6}$ & 275.24 & $40,451.92$ & $37,458.57$ & 2994.02 & $86,907.39$ \\
\hline Cork & $-99,460.39$ & 1062.36 & 227.88 & $1.82 \times 10^{-8}$ & $15,131.83$ & $639,943.54$ & $242,757.26$ & $396,681.89$ & $103,216.70$ \\
\hline Windows & $34,367.10$ & 186.00 & 10.76 & $4.69 \times 10^{-7}$ & 2468.35 & $554,928.09$ & $515,488.35$ & $40,354.22$ & $18,733.34$ \\
\hline PVC frame & $15,310.36$ & 39.91 & 4.48 & $4.34 \times 10^{-7}$ & 613.93 & $279,137.20$ & $253,620.39$ & $25,577.19$ & 5603.11 \\
\hline Total general & $-31,800.62$ & 1433.14 & 248.02 & $-4.53 \times 10^{-4}$ & $20,614.15$ & $2,142,284.63$ & $1,478,577.48$ & $605,075.80$ & $350,896.79$ \\
\hline
\end{tabular}

\section{Discussion}

The original stage of social housing, the intervention made, and an alternative proposal have been analyzed by carrying out an energy demand analysis, a daylighting and solar access analysis, and a life cycle analysis in order to explore the environmental performance before and after the intervention and the environmental impact of the materials used to refurbish the building.

The reduction of its energy demand is aligned to the sustainability principles as decreasing the demand decreases the energy consumption, thus the $\mathrm{CO}_{2}$ emissions. Daylighting reduces the use of artificial lighting, so it also reduces the $\mathrm{CO}_{2}$ emissions, although the implementation of light-emitting diode lamps has heavily reduced the lighting energy consumption. However, as reducing energy demand is a sign of achieving indoor thermal comfort, an adequate daylighting provides visual comfort, which is related to human health. Both aspects are aligned to the European goal "Putting energy efficiency first" [3].

Although sustainability in the building sector is associated with minimizing the $\mathrm{CO}_{2}$ emissions derived from the use stage of the building, actions can be made at the other life cycle stages. The $\mathrm{CO}_{2}$ equivalent emissions of the construction materials and products have a great impact during the product and the end-of-life stages [6]. The consideration of the sustainability throughout all building life cycle stages is one of the principles of what the authors call eco-efficiency.

Considering the impact of materials and minimizing the extraction of raw materials due to the recycle or the reuse of the manufactured and installed ones is one of the current goals of the European Union in order to get a resource-efficient building stock [23].

However, recycling and reusing are principles of the circular economy concept. One of the pillars of this concept is to focus on the design in order to make it easier to disassemble the building into its different components in order to be reused, repaired, remanufactured, or recycled [10]. Sustainability and circular economy are connected by their awareness of the environmental impact of human activities, with the circular economy being one way to achieve sustainability of the building sector [12]. 
This research faces the current European paradigm, towards a decarbonized and circular building stock, by exploring the deficiencies of a conventional current intervention on a building, based on the energy rehabilitation, promoted by the 'Renovation wave' initiative [13], with the constraint of the information provided by the owner and limited by the use of an unique BIM tool and its plugins for the different analyses.

The environmental performance analysis of the building, at all studied stages, has suffered some inconvenient issues derived from a non-intentional monitoring campaign, in terms of lack of sensors and the results provided, and from the limitations and the results provided by the used energy analysis tools.

However, the monitoring campaign, although not measuring indoor daylighting, the movement of blinds, or the energy consumption of each thermal equipment, provides information about the users' energy habits and, due to the differences with the energy models, can be interpreted that they lowered blinds in order to get thermal comfort during warm months.

The Spanish Energy Rating Assessment is based on a predefined operational profile, which cannot be modified and results in a disconnection between the energy model and the actual user performance. Furthermore, the tool used by the owner does not perform an hourly simulation, it parametrizes the building and compares the input data with a database of results. Those facts, disconnection to reality, and parametric-based energy rating, do not allow to compare the results or even calibrate the model. In addition, the campaign provided temperature and relative humidity measurements, but the energy rating model provides annual energy demand.

The mandatory use of BIM tools when working with public institutions is supposed to provide a positive impact on the development of a building project due to the use of a unique model by the different stakeholders. Based in this principle, the environmental and life cycle analyses were performed looking for plugins or tools inside BIM with a validated calculation engine.

After the security that provides the fact that the BIM tool can perform an energy analysis using EnergyPlus, a daylighting analysis using Radiance, and a life cycle analysis based on the current standards, there were several input data and software conditions that also separate the results from the actual performance and the monitored data.

These can be resumed as the assumption of equivalent constructive solutions, an annual schedule for operational conditions, inability to incorporate movable blinds, or the usage of US values for the environmental impact as there is no possibility to create materials inside the LCA plugin.

In addition to the problems derived from using one model for each analysis, at the moment of choosing an eco-efficient material there are also some troubles, as the known databases of construction materials and products with EPD are limited as are the items, so there is not so much variety when looking for eco-efficient materials.

However, the intervention on the building reduced the energy demand, also shown on the measurements, so it fulfils its original intention: An energy rehabilitation. Expanding the environmental analysis to daylighting and solar access, it was observed that at its original state, there were some dwellings falling outside the criteria, but after the refurbishment, due to lowering the glazing transparency, the dwellings can be said to be well daylit (maintaining blinds open all the time).

It has to be highlighted that blinds are open in the energy and daylighting analyses, so the results do not represent what is currently happening, but having the blinds open the results express the potential of daylighting and the potential of solar heat gains. It has to be kept in mind that sunlight (direct radiation) is beneficial for heating the spaces during winter but penalizes the cooling energy demand, as well as is beneficial for getting enough daylighting inside the building but excessive direct sunlight can provoke discomfort. Daylighting and Solar access should always be performed in order to balance the entrance of direct sunlight for getting visual comfort but without an excessive reduction of the solar heat gains when they are useful for thermal comfort.

Finally, looking for eco-efficient materials is difficult for non-experts as the databases are few and the offer of materials and products limited. However, if the stakeholder chooses alternative materials, 
even though the construction solution is not designed for disassembly, the environmental impact can be reduced, contributing to the European current goals.

\section{Conclusions}

The original stage of the building presented some energy performance deficiencies, especially in heating energy demand, highlighted during the monitoring campaign and the energy rating results. Consequently, a refurbishment intervention was proposed in order to solve the maintenance deficiencies but also to correct the energy performance of the building. This proposal, made in 2014, some years before the newest update of the minimum energy requirements of the thermal envelope elements, was composed by usual materials, without looking for reduce their environmental impact.

The monitoring campaign, covering the few months before the intervention and almost a year after, showed the hydrothermal indoor conditions. It can be observed how the dwellings monitored can achieve thermal comfort during warm and hot seasons naturally or using passive techniques as adaptive clothing, evaporative cooling, or night natural ventilation. However, even after the incorporation of thermal insulation in walls and roofs and the substitution of windows, the indoor conditions during winter remain with low temperatures and high relative humidity, although they have been improved.

The refurbishment intervention improves the energy demand rating as expected, especially the heating energy demand. The energy demand analysis, performed in EnergyPlus, of both stages is in concordance with the energy rating model but the quantities of energy demand differ as a consequence of the differences between both simulation models and engines. However, a more detailed monitoring campaign, recovering data of user performance and energy resource consumption, would be useful to validate the simulation model.

The daylighting and solar exposure analysis showed that, in general, the daylight provision was satisfactory, although at the first time, some dwellings had excessive direct sunlight, considering that blinds were considered open during simulations. As the intervention modified the transparency of windows, this problem was solved without needing to incorporate solar protection devices.

If the incorporation of solar protection devices was needed, a new solar exposure analysis was performed in order to know how those devices reduce the incidence of direct sunlight hours in the dwellings, that would mean a reduction of a positive heat load during winter.

The life cycle analysis of the intervention showed that cement-based materials had a high environmental impact and were the main contributors of ODP. It also showed that windows have a relevant rule as their impact is near the environmental impact of walls, but their surface is $25 \%$ of the vertical opaque area. Glazing and window frame were similar contributors, but the area covered by frame is very low compared to the area of glazing, thus highlighting the importance of the window frame material impact.

As the original proposal improved the energy performance and daylighting comfort, a proposal was carried out substituting cement-based materials, window frame material, and thermal insulation materials, in order to look for more eco-efficient alternatives. If the conductivity of the new materials is different, the thickness is changed in order to keep the transmittance of the original proposal.

A new life cycle analysis showed that using natural-based thermal insulation, along with reducing the environmental impact of the cement-based materials, can result in a positive Global Warming Potential and Ozone Depletion Potential by capturing $\mathrm{CO}_{2}$ and CFCs. However, not all the environmental impacts were reduced as the Primary Energy Demand increased for the new roof materials; and the Acidification Potential, Eutrophication Potential, and Smog Formation Potential increased for the new wall materials. Regarding window frame, PVC has a lower impact than aluminum frame, but the potential of reusing the aluminum versus the reuse or recycle of the PVC made the aluminum a higher contributor to the circular economy.

An integral eco-efficient analysis of refurbishment interventions, covering the energy performance, the lighting comfort, and the environmental impact of the materials, would help to achieve a 
decarbonized, resource efficient and circular building stock. However, considering the constrains and limitations of the tools and databases, higher efforts should be done to solve them and provide useful and easy-to-use resources for stakeholders.

Author Contributions: Conceptualization, P.M.-M., P.M.E., and R.M.; methodology and investigation, P.M.E.; formal analysis, P.M.E. and P.M.-M.; writing—original draft preparation and editing, P.M.E.; writing—review, P.M.-M. and R.M. All authors have read and agreed to the published version of the manuscript.

Funding: This paper and the costs for its publication in open access have been funded by the CircularBIM project (code 2019-1-ES01-KA2013-065962), an ERASMUS+ project co-funded by the European Union and within the framework of an initiative of 2019 (KA2, Strategic partnerships in the field of higher education), with the support of the Servicio Español para la Internacionalización de la Educación (SEPIE, Spain). This research was funded by the ERASMUS+Programme and by MAPEI SPAIN S.A. through the research contract "Implementation of Eco-efficient and Urban health measures in building renovation and urban regeneration for the requirement of new products in the construction sector-2nd phase" (Reference 3719/0632).

Acknowledgments: The authors want to thank David Moreno Rangel for his support in the development of this article.

Conflicts of Interest: The authors declare no conflict of interest.

\section{References}

1. European Commission. A Clean Planet for All. A European Strategic Long-Term Vision for a Prosperous, Modern, Competitive and Climate Neutral Economy; Communication from the Commission COM (2018) 773 Final; European Commission: Brussels, Belgium, 2018.

2. European Commission. The European Green Deal; Communication from the Commission COM (2019) 640 Final; European Commission: Brussels, Belgium, 2019.

3. European Commission. Clean Energy for All Europeans; Communication from the Commission COM (2019) 640 Final; European Commission: Brussels, Belgium, 2016.

4. European Commission. Sustainable Products in a Circular Economy-Towards an EU Product Policy Framework Contributing to the Circular Economy; Commission Staff Working Document SWD (2019) 91 Final; European Commission: Brussels, Belgium, 2019.

5. European Commission. A New Circular Economy Action Plan: For a Cleaner and More Competitive Europe; COM (2020) 98 Final; European Commission: Brussels, Belgium, 2020.

6. Márton, H. Resource Efficiency in the Building Sector; DG Environment FEA91117; Ecorys: Rotterdam, The Netherland, 2014.

7. Francesco, P.; Alice, M. Circular economy for the built environment: A research framework. J. Clean. Prod. 2017, 143, 710-718.

8. Ellen MacArthur Foundation. Circular Economy Reports \& Publications From The Ellen MacArthur Foundation. Available online: https://www.ellenmacarthurfoundation.org (accessed on 15 July 2015).

9. European Commission. Closing the Loop - An EU Action Plan for the Circular Economy; Communication from the Commission to the European Parliament, the Council, the European Economic and Social Committee and the Committee of the Regions COM(2015) 614 Final; European Commission: Brussels, Belgium, 2015.

10. Faculty of Architecture and the Built Environment|Delft University of Technology. Circular Built Environment. Available online: https://www.tudelft.nl/en/architecture-and-the-built-environment/research/ research-themes/circular-built-environment/ (accessed on 10 June 2020).

11. Geissdoerfer, M.; Savaget, P.; Bocken, N.M.P.; Hultink, E.J. The Circular Economy-A new sustainability paradigm? J. Clean. Prod. 2017, 143, 757-768. [CrossRef]

12. Anastasiades, K.; Blom, J.; Audenaert, A. Translating the circular economy to bridge construction: Lessons learnt from a critical literature review. Renew. Sustain. Energy Rev. 2020, 117, 109522. [CrossRef]

13. European Commission. Renovation wave|Energy. Available online: https://ec.europa.eu/energy/topics/ energy-efficiency/energy-efficient-buildings/renovation-wave_en (accessed on 8 June 2020).

14. European Commission. Commission Recommendation (EU) 2019/1019 of 7 June 2019 on building modernisation. Off. J. Eur. Union 2019, 165, 70-128.

15. European Commission. An EU Strategy on Heating and Cooling; Communication from the European Commission COM (2016) 51 Final; European Commission: Brussels, Belgium, 2016. 
16. RHC-ETIP. European Technology and Innovation Platform on Renewable Heating and Cooling. 2050 Vision for $100 \%$ Renewable Heating \& Cooling in Europe. Available online: https:/www.buildup.eu/en/practices/ publications/2050-vision-100-renewable-heating-cooling-europe (accessed on 21 January 2020).

17. The European Parliament and the Council of the European Union. Directive 2010/31/EU on the Energy Performance of Buildings. Off. J. Eur. Union 2010, 153, 13-35.

18. The European Parliament and the Council of the European Union. Directive 2012/27/EU on the energy efficiency, amending Directives 2009/125/EC and 2010/30/EU and repealing Directives 2004/8/EC and 2006/32/EC. Off. J. Eur. Union. 2012, 315, 1-56.

19. The European Parliament and the Council of the European Union. Directive (EU) 2018/844 amending Directive 2010/31/EU on the energy performance of buildings and Directive 2012/27/EU on energy efficiency. Off. J. Eur. Union 2018, 156, 75-91.

20. Kephalopoulos, S.; Geiss, O.; Barrero-Moreno, J.; D’Agostino, D.; Paci, D. Promoting Healthy and Highly Energy Performing Buildings in the European Union: National Implementation of Related Requirements of the Energy Performance Buildings Directive (2010/31/EU); Science for Policy report 978-92-79-70594-6; Joint Research Centre: Luxemburg, 2017.

21. European Commission. Impact Assessment Accompanying the Document Proposal for a Directive of the European Parliament and of the Council; Commission Staff Working Document SWD (2016) 414 Final; European Commission: Brussels, Belgium, 2016.

22. Aranda, J.; Zabalza, I.; Conserva, A.; Millán, G. Analysis of Energy Efficiency Measures and Retrofitting Solutions for Social Housing Buildings in Spain as a Way to Mitigate Energy Poverty. Sustainability 2017, 9, 1869. [CrossRef]

23. European Commission. Resource Efficiency Opportunities in the Building Sector; Communication from the Commission COM (2014) 445 Final; European Commission: Brussels, Belgium, 2014.

24. European Commission. Guidelines for the Waste Audits before Demolition and Renovation Works of Buildings; European Commission: Brussels, Belgium, 2018.

25. European Union. Level (s)_A Common EU Framework of Core Sustainability Indicators for Office and Residential Buildings. Parts 1 and 2: Introduction to Level(s) and How it Works; JCR Technical Reports; Publications Office of the European Union: Luxembourg, 2017.

26. European Commission. Circular Economy Principles for Buildings Design; European Commission: Brussels, Belgium, 2020.

27. Hertwich, E.; Lifset, R.; Pauliuk, S.; Heeren, N. Resource Efficiency and Climate Change: Material Efficiency Strategies for a Low-Carbon Future; Report of the International Resource Panel 978-92-807-3771-4; United Nations Environment Programme: Nairobi, Kenya, 2020.

28. Kunkel, S.; Kontonasiou, E.; Arcipowska, A.; Mariottini, F.; Atanasiu, B. Indoor Air Quality, Thermal Comfort and Daylight. Analysis of Residential Building Regulations in Eight EU Members; Buildings Performance Institute Europe: Brussells, Belgium, 2015.

29. Kepleis, N.E. The National Human Activity Pattern Survey (NHAPS): A Resource for Assessing Exposure to Environmental Pollutants; Lawrence Berkeley National Laboratory: Berkeley, CA, USA, 2001.

30. Dorizas, P.V.; De Groote, M.; Volt, J. The Inner Value of a Building: Linking Indoor Environmental Quality and Energy Performance in Building Regulation; Buildings Performance Institute Europe: Brussells, Belgium, 2018.

31. European Committee for Standardization. Energy Performance of Buildings_-Ventilation for Buildings-Part 1: Indoor Environmental Input Parameters for Design and Assessment of Energy Performance of Buildings Addressing Indoor Air Quality, Thermal Environment, Lighting and Acoustics-Module M1-6; Norma Española EN 16798-1:2019; AENOR: Madrid, Spain, 2019.

32. European Environment Agency. Environment and Human Health; Joint EEA-JRC Report 1725-9177; European Environment Agency: Bruselas, Belgium, 2013.

33. World Green Building Council. A Sustainable Built Environment at the Heart of Europe's Future; WorldGBC: Toronto, ON, USA, 2019.

34. De Transportes, M.; Urbana, M.Y.A.; De España, G. Boletín Estadístico Online-Información Estadística. Available online: https://apps.fomento.gob.es/BoletinOnline2/ (accessed on 8 June 2020).

35. Gobierno de España. Ministerio de Transición Ecológica y el Reto Demográfico. Available online: https://energia.gob.es/desarrollo/EficienciaEnergetica/CertificacionEnergetica/DocumentosReconocidos/ Paginas/procedimientos-certificacion-proyecto-terminados.aspx (accessed on 2 February 2020). 
36. Autodesk. Revit|BIM Software|Autodesk Official Store. Available online: https://www.autodesk.com/ products/revit/overview (accessed on 18 September 2019).

37. Autodesk. Autodesk Revit 2020|Help. Available online: https://help.autodesk.com/view/RVT/2020/ENU/ (accessed on 9 January 2020).

38. U.S. Department of Energy. EnergyPlus. Available online: https://energyplus.net (accessed on 18 September 2019).

39. Autodesk. Insight-High Performance and Sustainable Building Design Analysis. Available online: https://insight.autodesk.com/oneenergy (accessed on 9 January 2020).

40. Walter, B.; Arbree, A.; Bala, K.; Greenberg, D.P. Multidimensional Lightcuts; International Conference on Computer Graphics and Interactive Techniques: New York, NY, USA, 2006; pp. 1081-1088.

41. IESNA. Spatial Daylight Autonomy (sDA) and Annual Sunlight Exposure (ASE); LM-83-12; Illuminating Engineering Society of North America: New York, NY, USA, 2012.

42. KT Innovations. Tally. Available online: https://choosetally.com (accessed on 9 January 2020).

43. ISO/TC 207/SC 5. Life cycle assessment. In Environmental Management-Life Cycle Assessment_Principles and Framework; ISO 14040:2006; International Organization for Standardization: Geneva, Switzerland, 2006.

44. ISO/TC 207/SC 5. Life cycle assessment. In Environmental Management_Life Cycle Assessment-Requirements and Guidelines; ISO 14044:2006; International Organization for Standardization: Geneva, Switzerland, 2006.

45. ISO/TC 59/SC 17. Sustainability in buildings and civil engineering works. In Sustainability in Buildings and Civil Engineering Works—Core Rules for Environmental Product Declarations of Construction Products and Services; ISO 21930:2017; International Organization for Standardization: Geneva, Switzerland, 2017.

46. ISO/TC 59/SC 17. Sustainability in buildings and civil engineering works. In Sustainability in Building Construction - Framework for Methods of Assessment of the Environmental Performance of Construction Works-Part 1: Buildings; ISO 21931-1:2010; International Organization for Standardization: Geneva, Switzerland, 2010.

47. CEN/TC 350. Sustainability of construction works. In Sustainability of Construction Works-Environmental Product Declarations —Core Rules for the Product Category of Construction Products; EN 15804:2012+A2:2019; European Committee for Standardization: Brussels, Belgium, 2019.

48. CEN/TC 350. Sustainability of construction works. In Sustainability of Construction Works-Assessment of Environmental Performance of Buildings_Calculation Method; EN 15978:2011; European Committee for Standardization: Brussels, Belgium, 2011.

49. Sphera. Life Cycle Assessment LCA Software. Available online: http://www.gabi-software.com/america/ support/gabi/ (accessed on 15 April 2020).

50. The European Parliament and the Council of the European Union. Directive 2002/91/EC of the European Parliament and of the Council of 16 December 2002 on the energy performance of buildings. Off. J. Eur. Union 2003, 1, 65-71.

51. Gobierno de España. Real Decreto 2429/1979, de 6 de julio, por el que se aprueba la norma básica de edificación NBE-CT-79, sobre condiciones térmicas en los edificios. Bol. Of. Estado 1979, 253, 24524-24550.

52. National Centers for Environmental Information. Integrated Surface Database (ISD)|National Centers for Environmental Information. Available online: https://www.ncdc.noaa.gov/isd (accessed on 20 May 2020).

53. ISO/TC 163/SC 2. Calculation methods. In Hygrothermal Performance of Buildings_Calculation and Presentation of Climatic Data-Part 4: Hourly Data for Assessing the Annual Energy Use for Heating and Cooling; ISO 15927-4:2005; International Organization for Standardization: Geneva, Switzerland, 2005.

54. Climate.OneBuilding.Org. Available online: http://climate.onebuilding.org (accessed on 9 January 2020).

55. Ministerio de Fomento. Real Decreto 732/2019, de 20 de diciembre, por el que se modifica el Código Técnico de la Edificación, aprobado por el Real Decreto 314/2006, de 17 de marzo. Bol. Of. Estado 2019, 311, 140488-140674.

56. Gobierno de España. Ministerio para la Transición Ecológica y el Reto Demográfico. Available online: https:/energia.gob.es/desarrollo/EficienciaEnergetica/CertificacionEnergetica/DocumentosReconocidos/ normativamodelosutilizacion/1-Condiciones_tecnicas_procedimientos_para_evaluacion_eficiencia_ energetica.pdf (accessed on 2 February 2020).

57. Instituto de Tecnología de la Construcción de Cataluña-ITeC. Información Ambiental de Productos y Sistemas|BEDEC. Available online: https://itec.es/metabase/productos-sostenibles/0/0/0/ (accessed on 15 April 2020). 
58. Green Building Council España-GBCe. Declaración Ambiental de Productos-Materiales GBCe. Available online: http://materiales.gbce.es/declaracion-ambiental-de-productos/ (accessed on 15 April 2020).

59. Asif, M.; Muneer, T.; Kubie, J. Sustainability analysis of window frames. Build. Serv. Eng. Res. Technol. 2005, 26, 71-87. [CrossRef]

(C) 2020 by the authors. Licensee MDPI, Basel, Switzerland. This article is an open access article distributed under the terms and conditions of the Creative Commons Attribution (CC BY) license (http://creativecommons.org/licenses/by/4.0/). 